\title{
The zinc sensing receptor, ZnR/GPR39, controls proliferation and differentiation of colonocytes and thereby tight junction formation in the colon
}

\author{
L Cohen ${ }^{1}$, I Sekler $^{1}$ and M Hershfinkel ${ }^{*, 1}$
}

The intestinal epithelium is a renewable tissue that requires precise balance between proliferation and differentiation, an essential process for the formation of a tightly sealed barrier. Zinc deficiency impairs the integrity of the intestinal epithelial barrier and is associated with ulcerative and diarrheal pathologies, but the mechanisms underlying the role of $\mathrm{Zn}^{2+}$ are not well understood. Here, we determined a role of the colonocytic $\mathrm{Zn}^{2+}$ sensing receptor, $\mathrm{ZnR} / \mathrm{GPR} 39$, in mediating $\mathrm{Zn}^{2+}$-dependent signaling and regulating the proliferation and differentiation of colonocytes. Silencing of ZnR/GPR39 expression attenuated $\mathrm{Zn}^{2+}$-dependent activation of ERK1/2 and AKT as well as downstream activation of mTOR/p70S6K, pathways that are linked with proliferation. Consistently, ZnR/GPR39 silencing inhibited HT29 and Caco-2 colonocyte proliferation, while not inducing caspase-3 cleavage. Remarkably, in differentiating HT29 colonocytes, silencing of ZnR/GPR39 expression inhibited alkaline phosphatase activity, a marker of differentiation. Furthermore, Caco-2 colonocytes showed elevated expression of ZnR/GPR39 during differentiation, whereas silencing of ZnR/GPR39 decreased monolayer transepithelial electrical resistance, suggesting compromised barrier formation. Indeed, silencing of ZnR/GPR39 or chelation of $\mathrm{Zn}^{2+}$ by the cell impermeable chelator CaEDTA was followed by impaired expression of the junctional proteins, that is, occludin, zonula-1 (ZO-1) and E-cadherin. Importantly, colon tissues of GPR39 knockout mice also showed a decrease in expression levels of Z0-1 and occludin compared with wildtype mice. Altogether, our results indicate that ZnR/GPR39 has a dual role in promoting proliferation of colonocytes and in controlling their differentiation. The latter is followed by ZnR/GPR39-dependent expression of tight junctional proteins, thereby leading to formation of a sealed intestinal epithelial barrier. Thus, ZnR/GPR39 may be a therapeutic target for promoting epithelial function and tight junction barrier integrity during ulcerative colon diseases.

Cell Death and Disease (2014) 5, e1307; doi:10.1038/cddis.2014.262; published online 26 June 2014

The intestinal epithelial barrier, located at the interface between the body and the digestive system lumen, facilitates electrolyte and nutrient absorption while protecting against permeation of antigenic, toxic or infectious materials. ${ }^{1}$ Stressful conditions in the intestinal lumen require rapid and continuous renewal of the epithelial layer, ${ }^{2}$ which occur through tightly regulated and balanced proliferation, migration and differentiation processes. ${ }^{3}$

$\mathrm{Zn}^{2+}$ deficiency leads to a reduction of epithelial cell proliferation rate, thus limiting renewal of gastrointestinal mucosa, but it also impairs barrier function, increases permeability and enhances cell death. ${ }^{4,5} \mathrm{Zn}^{2+}$ supplementation reverses these processes and restores integrity of colon epithelium. ${ }^{5-7}$ Importantly, $\mathrm{Zn}^{2+}$ supplementation reduces diarrheal disease activity index ${ }^{8,9}$ and is effective in decreasing severity of histological and clinical scores in in vivo models of ulcerative colitis. ${ }^{10,11}$ Despite these observations, the signaling pathways linking $\mathrm{Zn}^{2+}$ to intestinal epithelial function or integrity are poorly understood.

We identified a $\mathrm{Zn}^{2+}$ sensing receptor, $\mathrm{ZnR}$, which links between changes in extracellular $\mathrm{Zn}^{2+}$ and major intracellular signaling pathways. Functional studies indicated that $\mathrm{ZnR}$ is a Gq-coupled receptor, which triggers inositol 1,4,5-trisphosphate (IP3)-dependent release of intracellular $\mathrm{Ca}^{2+},{ }^{12}$ leading to activation of mitogen-activated protein (MAP) and phosphoinositide 3 (PI3) kinase pathways. ${ }^{13,14}$ Recent studies showed that the $\mathrm{Zn}^{2+}$-dependent $\mathrm{Ca}^{2+}$ rise is mediated by the G-protein-coupled receptor GPR39, in colonocytes. ${ }^{15} \mathrm{ZnR} / \mathrm{GPR} 39$ mediates recovery from acidic $\mathrm{pH}$ by upregulation of $\mathrm{Na}^{+} / \mathrm{H}^{+}$exchange in colonocytic and keratinocytic cell lines as well as in native colon epithelial cells, demonstrating the important role of this receptor in epithelial physiology. ${ }^{13,15,16}$ Finally, ZnR/GPR39 enhances colonocytes survival from butyrate induced stress. ${ }^{15}$ Notably, GPR39 knockout (KO) mice show symptoms of $\mathrm{Zn}^{2+}$ deficiency: accelerated gastric emptying and increased fecal secretion. ${ }^{17}$ However how $\mathrm{Zn}^{2+}$ or ZnR/GPR39 signaling promote colon epithelial function is not well understood. Here we show that $\mathrm{ZnR} / \mathrm{GPR} 39$ regulates extracellular $\mathrm{Zn}^{2+}$ dependent proliferation and differentiation processes in colonocytes. Furthermore, we show that ZnR/GPR39 is essential for expression and localization of tight junction

\footnotetext{
${ }^{1}$ Department of Physiology and Cell Biology, Faculty of Health Science, Ben-Gurion University of the Negev, Beer-Sheva, Israel

${ }^{*}$ Corresponding author: M Hershfinkel, Department of Physiology and Cell Biology, Faculty of Health Science, Ben-Gurion Ave. POB 653, Ben-Gurion University of the Negev, Beer-Sheva 84105, Israel. Tel: +972 8 6477318; Fax: +972 8 6477627; E-mail:hmichal@ bgu.ac.il

Abbreviations: ZnR, zinc sensing receptor; MAP kinase, mitogen-activated protein kinases; PI3 kinase, phosphoinositide 3-kinase; IP3, inositol 1,4,5-trisphosphate; ERK, extracellular regulating kinase; ZO-1, zonula-1; CaEDTA, calcium ethylenediaminetetraacetic acid; TEER, transepithelial electrical resistance; AP, alkaline phosphatase

Received 11.2.14; revised 11.4.14; accepted 05.5.14; Edited by R Johnstone
} 
proteins in vitro and in vivo, and thereby regulates the formation of the colon epithelial barrier.

\section{Results}

Previous studies showed that $\mathrm{Zn}^{2+}$ activates kinase pathways in colonocytes. $\mathrm{Zn}^{2+}$ has pleiotropic interactions with multiple proteins and signaling pathways, and while functional analysis suggested a role for ZnR/GPR39 in mediating kinase activation, the specific role of the receptor was not resolved. We, therefore, initially used molecular silencing of $\mathrm{ZnR} /$ GPR39 to determine whether $\mathrm{Zn}^{2+}$ specifically activates signaling via this receptor. ZnR/GPR39 mRNA levels in HT29 colonocytes (Figure 1a, left panel) transfected with siGPR39 were only $35 \pm 2 \%$ of their levels in control (siCONT) cells, and a similar reduction in GPR39 expression levels was monitored in siGPR39-transfected cells (Figure 1a, right panel). Consistent with previous studies, reduced expression of $\mathrm{ZnR} / \mathrm{GPR} 39$ resulted in attenuated $\mathrm{Zn}^{2+}$-dependent $\mathrm{Ca}^{2+}$ response (Figure $1 \mathrm{~b}$ ), a hallmark of $\mathrm{ZnR}$ signaling. ${ }^{12}$ The ATPdependent metabotropic $\mathrm{Ca}^{2+}$ responses in siGPR39 cells were similar to those in siCONT, indicating that the IP3 pathway remained intact in siGPR39 cells. Importantly, extracellular $\mathrm{Zn}^{2+}$-dependent phosphorylation of extracellular regulating kinase $(\mathrm{ERK}) 1 / 2$ and $\mathrm{AKT}^{13}$ were attenuated in
siGPR39 cells to only $56 \pm 11 \%$ and $52 \pm 6 \%$, respectively, of the level monitored in siCONT cells (Figures 1c and d). Note that the residual $\mathrm{ZnR} / \mathrm{GPR} 39$ level in siGPR39 cells is similar to the $\mathrm{Zn}^{2+}$-dependent activation of ERK1/2 and AKT in these cells. Thus, our results indicate that $\mathrm{ZnR} / \mathrm{GPR} 39$ is a major mediator of $\mathrm{Zn}^{2+}$ signaling in colonocytes.

Activation of the mammalian target of rapamycin (mTOR) signaling pathway, downstream to the PI3K cascade, leads to cell growth and proliferation. We, therefore, asked if $\mathrm{ZnR} /$ GPR39 mediates $\mathrm{Zn}^{2+}$-dependent activation of $\mathrm{mTOR}$ and its downstream target p70S6k. HT29 colonocytes were treated with $\mathrm{Zn}^{2+}(100 \mu \mathrm{M}, 10 \mathrm{~min})$ in the presence or absence of the MEK1/2 and PI3K inhibitors $\mathrm{u} 0126$ ( $1 \mu \mathrm{M}, 30 \mathrm{~min})$ and wortmannin $(30 \mathrm{nM}, 30 \mathrm{~min})$, respectively. Application of $\mathrm{Zn}^{2+}$ resulted in a $62 \pm 8 \%$ increase in phosphorylated $\mathrm{mTOR}$ (p-mTOR), compared with control non-treated cells (Figure 2a). Inhibition of the MAPK or PI3K pathways reversed the effect of $\mathrm{Zn}^{2+}$ on mTOR activation ( $57 \pm 12 \%$ and $64 \pm 3 \%$ of the $\mathrm{Zn}^{2+}$-treated cells, respectively) indicating that both signaling pathways are required to mediate $\mathrm{mTOR}$ activation by $\mathrm{Zn}^{2+}$ (Figure 2a). Application of $\mathrm{Zn}^{2+}$ also increased the phosphorylation of $\mathrm{p} 70 \mathrm{~S} 6 \mathrm{~K}$ by $47 \pm 4 \%$ compared with control cells (Figure $2 \mathrm{~b}$ ). The stimulatory effect of $\mathrm{Zn}^{2+}$ on p70S6K was reversed by $u 0126$ and wortmannin $(57 \pm 8 \%$ and $58 \pm 15 \%$ of the $\mathrm{Zn}^{2+}$-treated cells, respectively), indicating
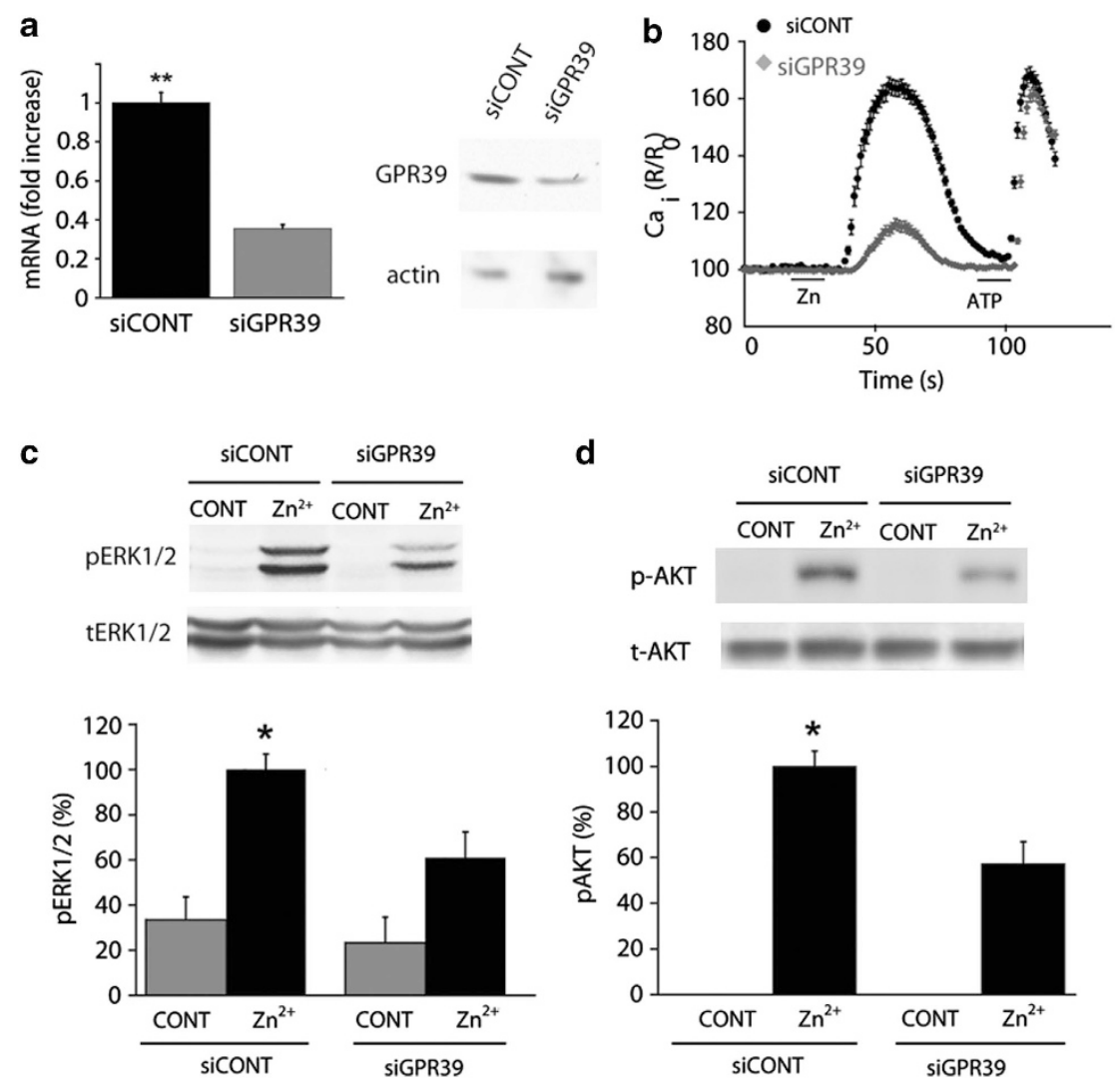

Figure $1 \mathrm{ZnR} / \mathrm{GPR} 39$ mediates $\mathrm{Zn}^{2+}$-dependent activation of ERK1/2 and AKT in HT29 colonocytes. HT29 cells were transfected with siGPR39 or siCONT constructs. (a) Left panel: real time PCR analysis of GPR39 mRNA levels in siCONT and siGPR39 cells. Right panel: representative immunoblots of ZnR/GPR39 expression and actin, used for loading control. (b) $\mathrm{Ca}^{2+}$ responses were monitored in HT29 cells loaded with Fura-2 following $\mathrm{Zn}^{2+}(200 \mu \mathrm{M})$ and subsequently ATP $(25 \mu \mathrm{M})$ application in $\mathrm{Ca}^{2+}$-free Ringer's solution, at the indicated times. (c, d) AKT and ERK1/2 phosphorylation in HT29 cells was monitored after application of Zn ${ }^{2+}(100 \mu \mathrm{M}, 10 \mathrm{~min})$ in Ringer's solution. Immunoblots using antibodies against phospho- or total- ERK1/2 (C) and AKT (D) are shown (upper panels). Phosphorylated ERK1/2 and AKT levels were normalized to total ERK1/2 and AKT levels, respectively, and are presented as percentage of the phosphorylation induced by $\mathrm{Zn}^{2+}$ in siCONT cells. $\left(n>3\right.$; $\left.{ }^{*} P<0.05\right)$ 
a

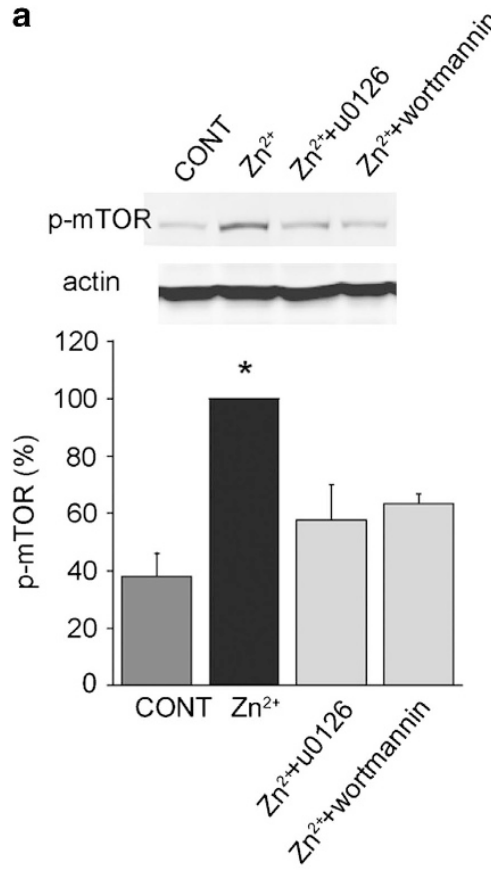

C

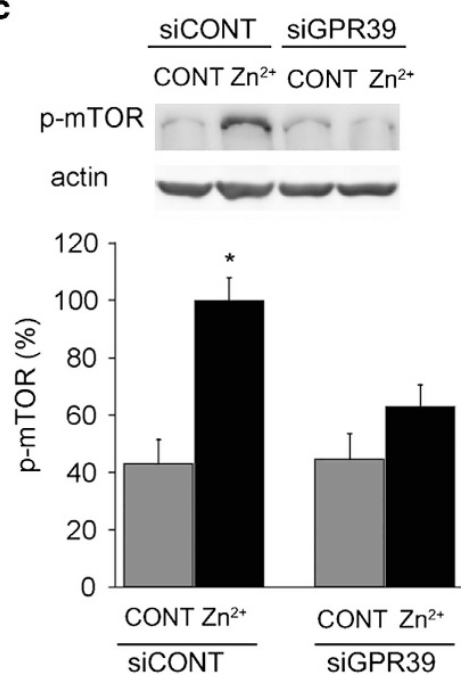

b

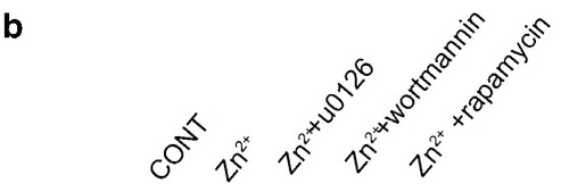

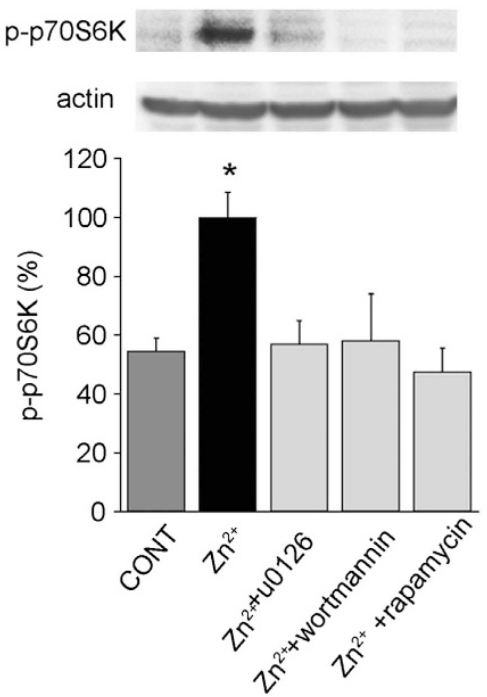

d

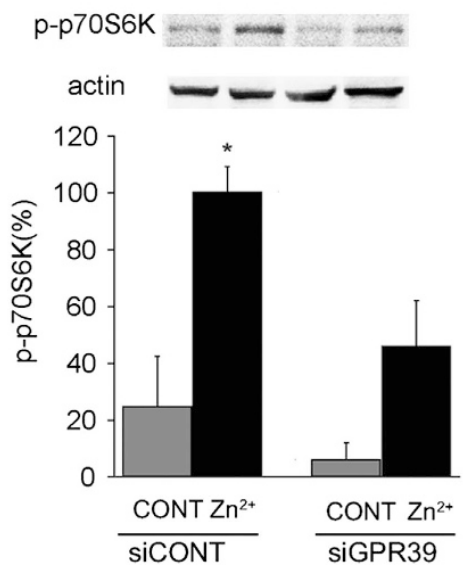

Figure 2 ZnR/GPR39 mediates $\mathrm{Zn}^{2+}$-dependent activation of mTOR and p70S6K via the MAPK and PI3K pathways. (a, b) HT29 cells were treated with $\mathrm{Zn}{ }^{2+}(100 \mu \mathrm{M}$, $10 \mathrm{~min}$ ) in the presence or absence of the indicated inhibitors (u0126 $1 \mu \mathrm{M}, 30 \mathrm{~min}$; wortmannin $30 \mathrm{nM}, 30 \mathrm{~min}$; and rapamycin $100 \mathrm{nM}, 1 \mathrm{~h}$ ) in Ringer's solution. Immunoblots using specific antibodies against phospho-mTOR, pospho-p70S6K and actin as control are shown (upper panels). Phosphorylated mTOR and p70S6K were normalized to actin levels, and are presented as percentage of the phosphorylation induced by $\mathrm{Zn}^{2+}$. (c, d) HT29 cells transfected with siGPR39 or siCONT constructs, as in figure 1, were treated with $\mathrm{Zn}^{2+}(100 \mu \mathrm{M}, 10 \mathrm{~min})$. Shown are immunoblots (upper panels) and quantification, as percentage of the phosphorylation induced by $\mathrm{Zn}^{2+}$ in siCONT cells. $\left(n=3 ;{ }^{*} P<0.05\right)$

that the signaling triggered by $\mathrm{Zn}^{2+}$ was mediated via $\mathrm{ZnR}$ dependent MAPK and PI3K pathways. Rapamycin (100 nM, $1 \mathrm{~h}$ ), inhibitor of the mTOR complex 1 (mTORC1), reduced $\mathrm{Zn}^{2+}$-dependent activation of p70S6K to $59 \pm 12 \%$ of the $\mathrm{Zn}^{2+}$-treated cells, a level similar to that found in the control cells, indicating that $\mathrm{Zn}^{2+}$-dependent phosphorylation of p70S6K is mediated by mTORC1. The stimulatory effect of $\mathrm{Zn}^{2+}$ was maintained in cells transfected with a scrambled siRNA construct (siCONT), but in ZnR/GPR39-silenced cells (siGPR39) $\mathrm{Zn}^{2+}$ did not trigger a significant rise in $\mathrm{p}-\mathrm{mTOR}$ or p70S6K levels $\left(52 \pm 8 \%\right.$ and $42 \pm 17 \%$ of the $\mathrm{Zn}^{2+}$-treated
siCONT cells, respectively, Figures $2 \mathrm{c}$ and d). Thus, $\mathrm{ZnR} / \mathrm{GPR} 39$ silencing reverses the effects of $\mathrm{Zn}^{2+}$ on activation of MAPK, PI3K, mTOR and p70S6K, indicating that $\mathrm{Zn}^{2+}$-dependent activation of these pathways in colonocytes is mediated by ZnR/GPR39.

Next, we studied the role of ZnR/GPR39 in enhancing HT29 colonocytes proliferation. As several days of culturing are required to determine proliferation rates and cells may not retain the siRNA constructs, we generated a stable $\mathrm{ZnR} /$ GPR39-silenced cell line using shRNA sequences for GPR39, which effectively reduced its mRNA levels (Figure 3a). 
We compared the proliferation rate of shGPR39 cells and cells stably transfected with a scrambled shRNA (shCONT) that served as a control. Already on the fourth day, the number of control cells (shCONT) was about twofold higher than shGPR39-silenced cells $\left((122 \pm 19) \times 10^{3}\right.$ and $(52 \pm 16) \times 10^{3}$ cells, respectively, Figure $3 b)$. To further study the role of ZnR/GPR39 in colonocytes proliferation, we determined the growth of Caco-2 cells stably transfected with the same shGPR39 construct that was used for HT29 cells (Figure 3). Silencing of GPR39 lowered ZnR/GPR39 mRNA levels
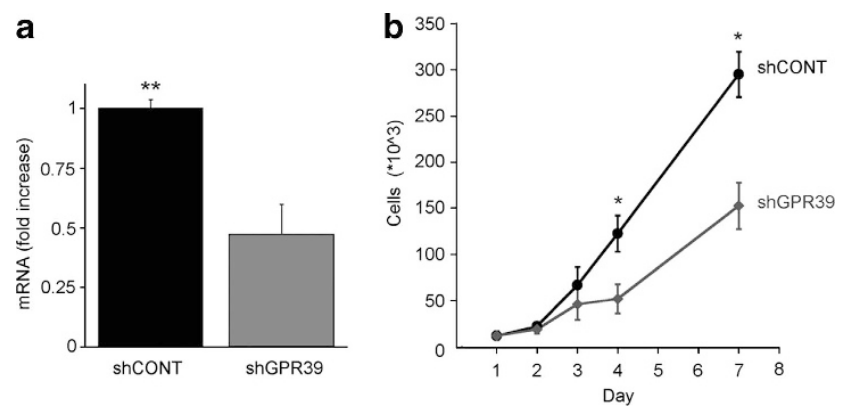

Figure 3 ZnR/GPR39 expression enhances HT29 colonocytes proliferation. HT29 cells were infected with DNA sequences coding for shRNAs compatible with ZnR/GPR39 (shGPR39) or a scrambled sequence (shCONT), as described in Experimental Procedures. (a) Real time PCR of GPR39 mRNA levels in shCONT and shGPR39 cells. (b) Cells were seeded on 96-well plates and allowed to proliferate for 7 days. Cells were fixed at the indicated times, and the SRB colorimetric assay was used to determine cell numbers. $\left(n=3\right.$; $\left.{ }^{*} P<0.05\right)$
(Figure 4a, left panel) as well as the protein expression level (Figure $4 \mathrm{a}$, right panel). Consistent with the results obtained for HT29 cells, ${ }^{15}$ knockdown of ZnR/GPR39 expression in Caco-2 cells was followed by complete inhibition of the $\mathrm{Zn}^{2+}$-dependent $\mathrm{Ca}^{2+}$ responses but not the metabotropic $\mathrm{Ca}^{2+}$ responses triggered by ATP (Figure 4b). Finally, proliferation of the Caco-2 shGPR39 cells was reduced (by about twofold) compared with that of shCONT cells, following 7 days of culture (Figure 4c). Altogether, our data indicate that $\mathrm{ZnR} / \mathrm{GPR} 39$ mediates the $\mathrm{Zn}^{2+}$-dependent proliferation of colonocytes.

In the intestinal epithelium, colonocytes undergo a switch from proliferation to differentiation. ${ }^{18,19}$ Previous studies suggested that $\mathrm{Zn}^{2+}$ promotes coloncytes differentiation, ${ }^{20}$ but whether the $\mathrm{ZnR} / \mathrm{GPR} 39$ may also promote this process is unknown. To study the role of ZnR/GPR39, early differentiation was induced in HT29 colonocytes by exposure to physiological concentrations of the short chain fatty acid butyrate $(5 \mathrm{mM}, 48 \mathrm{~h}) .{ }^{21,22}$ HT29 cells differ in their sensitivity to NaB-dependent cell death versus differentiation, ${ }^{23}$ indeed, $30 \mathrm{mM}$ butyrate were required to trigger cell death ${ }^{15}$ in the cells used in the current study. We compared the activation of intestinal alkaline phosphatase (AP), which serves as a well-established colonocyte differentiation marker, ${ }^{21}$ in ZnR/GPR39-silenced HT29 cells (shGPR39) and control cells (shCONT) treated with butyrate. Consistent with previous studies, shCONT HT29 cells treated with butyrate showed a dramatic increase of $88 \pm 7 \%$ in AP activity compared with non-treated cells (Figure 5a). In contrast, AP activation was
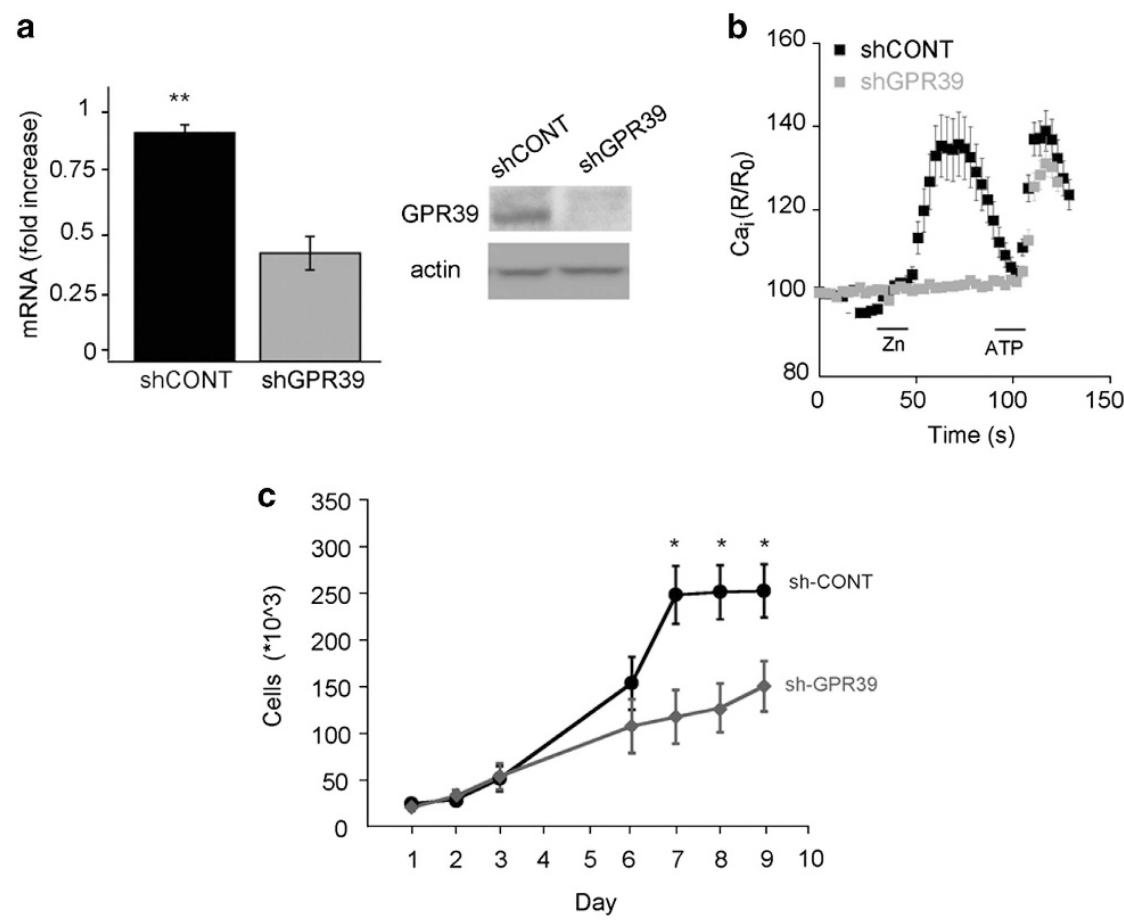

Figure 4 ZnR/GPR39 signaling in Caco-2 colonocytes enhances proliferation. Caco-2 colonocytes were infected with lentivirus encoding shRNAs compatible with ZnR/GPR39 (shGPR39) or a scrambled sequence (shCONT), as described in Experimental Procedures. (a) Left panel: levels of ZnR/GPR39 mRNA in Caco-2 cells expressing shCONT and shGPR39 were determined using real time PCR. Right panel: representative immunoblots of ZnR/GPR39 and actin, used as loading control, are shown. (b) $\mathrm{Ca}^{2+}$ responses in cells loaded with Fura-2 were monitored following application of $\mathrm{Zn}^{2+}(200 \mu \mathrm{M})$ and subsequently ATP $(25 \mu \mathrm{M})$ in Ca ${ }^{2+}$ free Ringer's solution. (c) Cells were seeded on 96 -well plates and allowed to proliferate of 9 days. Cells were fixed at the indicated times, and the SRB colorimetric assay was used to determine cell numbers. $\left(n=3 ;{ }^{*} P<0.05\right)$ 

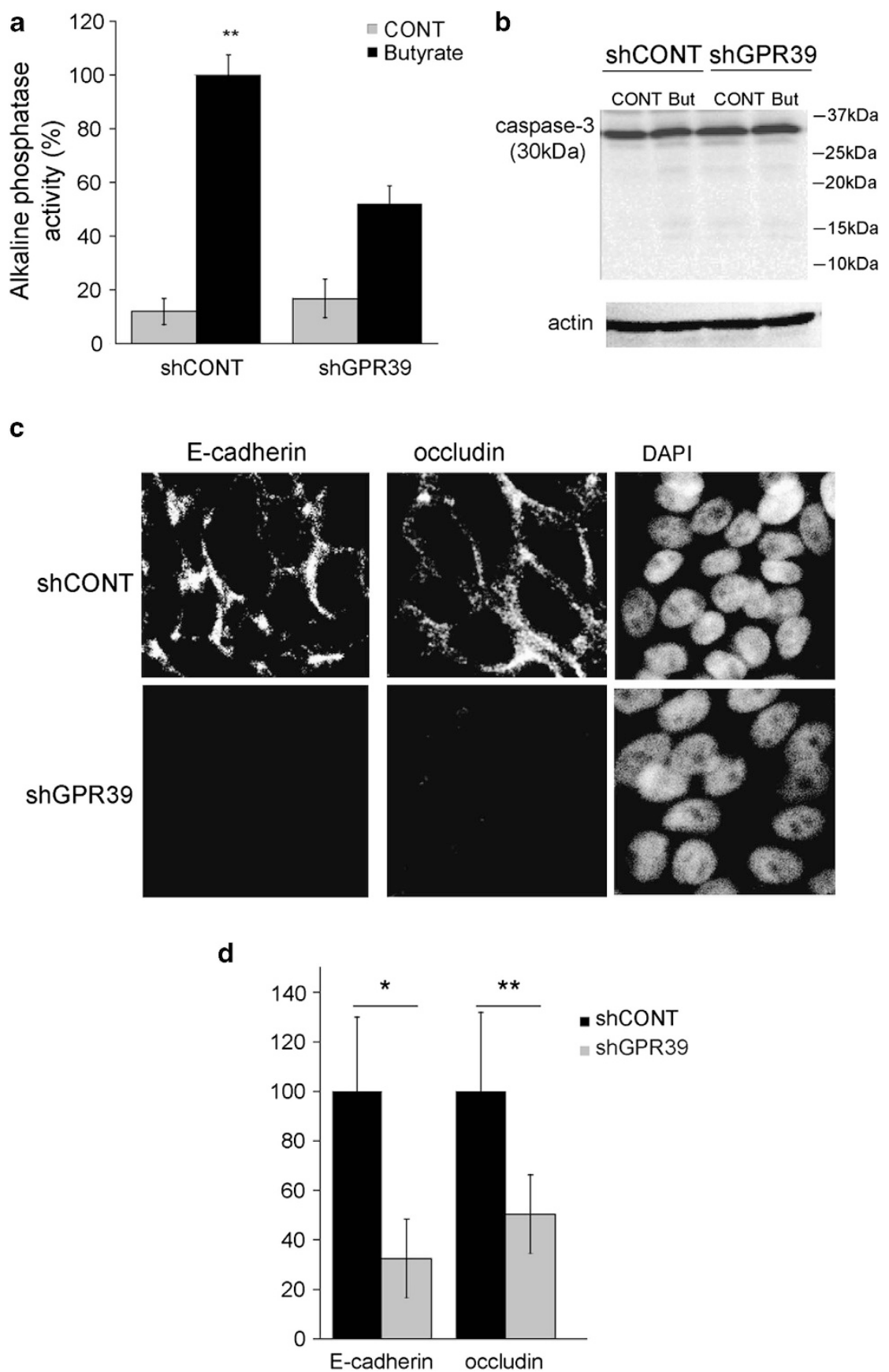

Figure 5 ZnR/GPR39 controls HT29 colonocytes differentiation. HT29 cells infected with lentivirus encoding shRNAs compatible with ZnR/GPR39 (shGPR39) or a scrambled non-coding sequence (shCONT), as described above, were treated with butyrate ( $5 \mathrm{mM}, 48 \mathrm{~h})$. (a) Alkaline Phosphatase (AP) expression was measured and was normalized to protein concentration. Results are shown as percentage of activity in shCONT cells treated with butyrate. (b) Caspase-3 cleavage following butyrate treatment in shCONT and shGPR39 HT29 cells. Representative immunoblots of caspase-3 expression and actin, used for loading control. (c) Immunofluorescence images of E-cadherin and occludin expression, and DAPI staining for nuclei detection following the same experimental procedure as in a. (d) Quantitative analysis of E-cadherin and occludin expression levels from images as presented in $\mathbf{b}$, shown as percentage of expression level in control cells. $\left(n=3 ;{ }^{*} P<0.05\right)$

impaired when ZnR/GPR39 expression was reduced by shGPR39, to only $52 \pm 7 \%$ of its level in shCONT cells treated with butyrate (Figure 5a), indicating that ZnR/GPR39 mediates the $\mathrm{Zn}^{2+}$-dependent HT29 differentiation. As decreased AP activity could also result from increased apoptosis, due to butyrate treatment or ZnR/GPR39 silencing, we analyzed caspase-3 cleavage following the same experimental procedure as in Figure $5 \mathrm{a}$, and found no activation of this caspase (Figure 5b), arguing against an apoptotic effect. Our results, therefore, indicate that ZnR/GPR39 induces differentiation of the colonocytes.

The development of junctional complexes is a hallmark of colonocytes differentiation and formation of the tight seal of the intestinal barrier. We, therefore, asked if ZnR/GPR39 
regulates the expression of junctional complexes. Cells were infected (shGPR39 or shCONT) and treated with butyrate as in Figure 5a, and we monitored the expression of occludin, a tight junctions protein, and E-cadherin, an adhering junctions protein. Although HT29 cells do not fully differentiate and localization of junctional proteins is not complete during the first $48 \mathrm{~h},{ }^{24-26}$ the rapid turnover $\left(t_{1 / 2}\right.$ of $5 \mathrm{~h}$ ) of junctional proteins allows monitoring of changes in their expression level during this phase. ${ }^{27,28}$ Immunostaining of the junctional proteins, occludin and E-cadherin, in shCONT cells showed mostly peripheral localization of both proteins following treatment with butyrate (Figure 5c). Quantitative analysis of the immunofluorescence signal indicated that shGPR39silenced HT29 cells exhibit significantly lower expression levels of occludin and E-cadherin $(54 \pm 26 \%$ and $50 \pm 15 \%$, respectively; Figures 5c and d) compared with ZnR/GPR39 (shCONT) expressing cells. Analysis of nuclear staining by DAPI did not exhibit differences in nuclear morphology between the shGPR39 cells compared with shCONT cells (Figure 5c). Thus, ZnR/GPR39 is clearly linked to enhanced expression level of the junctional proteins during early differentiation of HT29 colonocytes.

Caco-2 colonocytes differentiate spontaneously upon reaching confluence in culture. ${ }^{29}$ To determine if $\mathrm{ZnR} /$ GPR39 is involved in their differentiation, we first compared mRNA levels of GPR39 between differentiating (4 or 10 days of post-confluent culture), and proliferating cells (seeded at $30 \%$ confluence and allowed to proliferate for 4 days). Real time PCR analysis showed that in differentiating Caco-2 cells (4 days in culture) ZnR/GPR39 mRNA levels were significantly elevated (2.3 \pm 0.4 -fold) compared with ZnR/GPR39 mRNA in proliferating cells (Figure $6 a$, left panel). Further increase in ZnR/GPR39 mRNA levels, to $6.9 \pm 1.6$ fold, was monitored when cells were allowed to fully differentiate (10 days in culture). The ZnR/GPR39 protein expression levels in the differentiated cells also increased, consistent with the mRNA analysis (Figure 6a, right panel). Thus, we asked if extracellular $\mathrm{Zn}^{2+}$ regulates formation of the junctional complexes in differentiated Caco-2 colonocytes. As colonocytes secrete $\mathrm{Zn}^{2+}$, which may activate ZnR/GPR39 endogenously, we buffered extracellular $\mathrm{Zn}^{2+}$ concentration using the cell impermeable $\mathrm{Zn}^{2+}$ chelator calcium ethylenediaminetetraacetic acid (CaEDTA) and did not add more of this metal ion. Immunostaining of occludin and zonula-1 (ZO-1) at tight junctions and E-cadherin at adhering junctions showed that in control monolayers, grown without CaEDTA, all three proteins are expressed and localized to the periphery of the cells (Figure $6 \mathrm{~b}$ ). In contrast, the addition of $100 \mu \mathrm{M}$ CaEDTA strongly impaired the expression of all three proteins. As shown, expression levels of occludin, ZO-1 and E-cadherin were reduced to $16 \pm 9 \%, 37 \pm 12 \%$ and $14 \pm 4 \%$ of the control cells, respectively (Figure 6c). The addition of $500 \mu \mathrm{M}$ CaEDTA resulted in a similar reduction of the junctional proteins expression levels (Figures $6 b$ and $c$ ), indicating that low concentration of the $\mathrm{Zn}^{2+}$ chelator is sufficient to reverse the effect of $\mathrm{Zn}^{2+}$ and inhibit junctional complexes formation. Nuclear morphology, as monitored by DAPI staining, was similar in the control cells and CaEDTA-treated cells (Figure 6b). Consistently, enhanced cleavage of caspase-3 was not monitored in CaEDTA-treated cells compared with controls (Figure 6d). Thus, $\mathrm{Zn}^{2+}$ removal, as performed here, did not enhance apoptotic cell death.

To directly determine the role of ZnR/GPR39 in promoting formation of the epithelial barrier and regulating expression of junctional proteins, we silenced ZnR/GPR39 expression. Caco-2 cells were stably infected with shCONT or shGPR39 plasmids (as in Figure 5) and grown to monolayers. Cells were allowed to differentiate for 10 days, and transepithelial electrical resistance (TEER) was compared between shCONT and shGPR39 cells. ZnR/GPR39 silencing was followed by decreased TEER values, reaching only $49 \pm 14 \%$ of those of shCONT cells (Figure 7a). Similar to the effect observed in HT29 cells, silencing of ZnR/GPR39 in differentiating Caco-2 cells did not induce caspase-3 cleavage (Figure 7b). Analysis of the cellular distribution of occludin, ZO-1, and E-cadherin indicated that all three junctional proteins were localized to the membrane in shCONT Caco-2 colonocytes, thus supporting proper formation of the barrier. In contrast, shGPR39 cells showed dramatically lower expression levels of all proteins (Figures 7c and d). Expression levels of occludin, ZO-1 and E-cadherin were decreased in the shGPR39 Caco-2 monolayers to $11 \pm 6 \%, 19 \pm 9 \%$, and $26 \pm 12 \%$, respectively, compared with their expression in shCONT cells (Figure 7d). Moreover, E-cadherin exhibited diffused and partial cytoplasmatic pattern, in contrast to its peripheral localization in control cells (Figure 7c). DAPI staining of cell nuclei was similar in shCONT and shGPR39 Caco-2 cells and did not indicate apoptotic cells death (Figure 7c). Altogether our results obtained with HT29 and Caco-2 colonocytes, suggest a major role for ZnR/GPR39 in colonocyte differentiation.

Finally, to determine the role of ZnR/GPR39 in barrier formation in vivo, we compared the expression of junctional complexes in colon tissue obtained from wildtype (WT) and ZnR/GPR39 KO mice. Immunofluorescence analysis of occludin and ZO-1 showed that expression of the two proteins was appropriately localized at the brush border of colonocytes in WT mice (Figure 8). In contrast, in colon tissue from ZnR/ GPR39 KO mice, we found a dramatic decrease in the expression of tight junction proteins, occludin and ZO-1. Surprisingly, expression of the adhering junction protein E-cadherin was similar in WT and GPR39 KO mice (see discussion). These results point towards a crucial role for $\mathrm{ZnR} /$ GPR39 in formation of tight junctions and in sealing the intestinal barrier in vivo.

\section{Discussion}

Zinc is essential for intestinal epithelium renewal and is directly involved in crypt cell proliferation ${ }^{30}$ and epithelial intestinal cell differentiation, ${ }^{20}$ whereas zinc deficiency is associated with suppression of colonocyte proliferation. ${ }^{20}$ Moreover, many studies underscored the importance of extracellular $\mathrm{Zn}^{2+}$ in cellular signaling associated with proliferation of colonocytes. For example, $\mathrm{Zn}^{2+}$ was linked to regulation of the MAPK pathway, ${ }^{31,32}$ and was also reported to activate the PI3 pathway. ${ }^{33,34}$ The specific receptor for extracellular $\mathrm{Zn}^{2+}, \mathrm{ZnR} / \mathrm{GPR} 39$, is functional in colonocytes and enhances colonocytes survival. ${ }^{15}$ Here, we show that ZnR/GPR39 is essential for mediating 
a

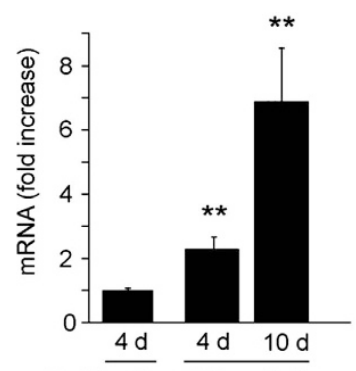

Proliferating $\overline{\text { Differentiating }}$

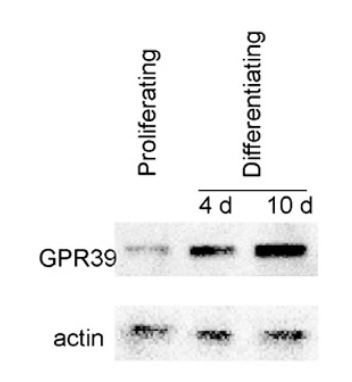

b

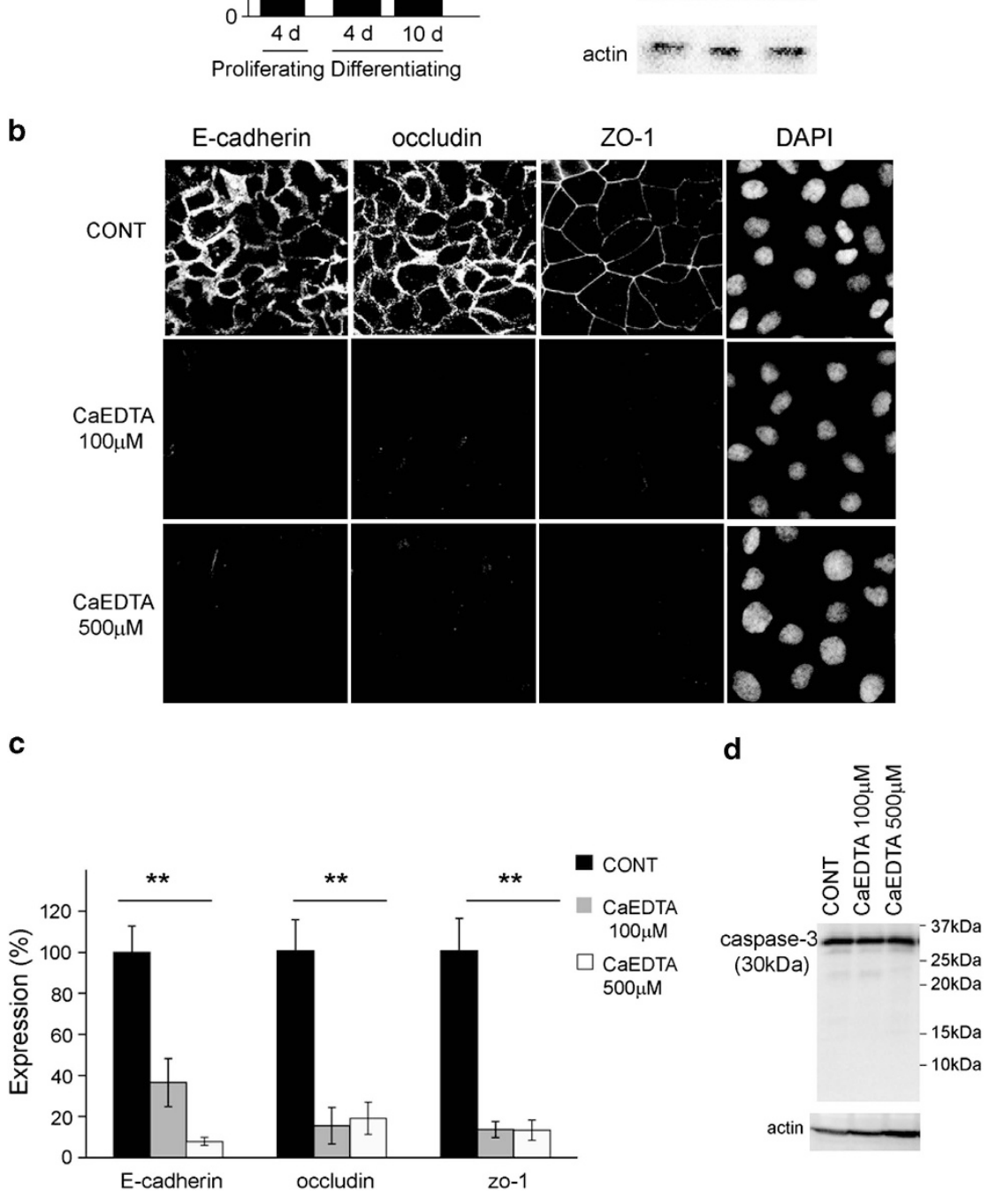

C

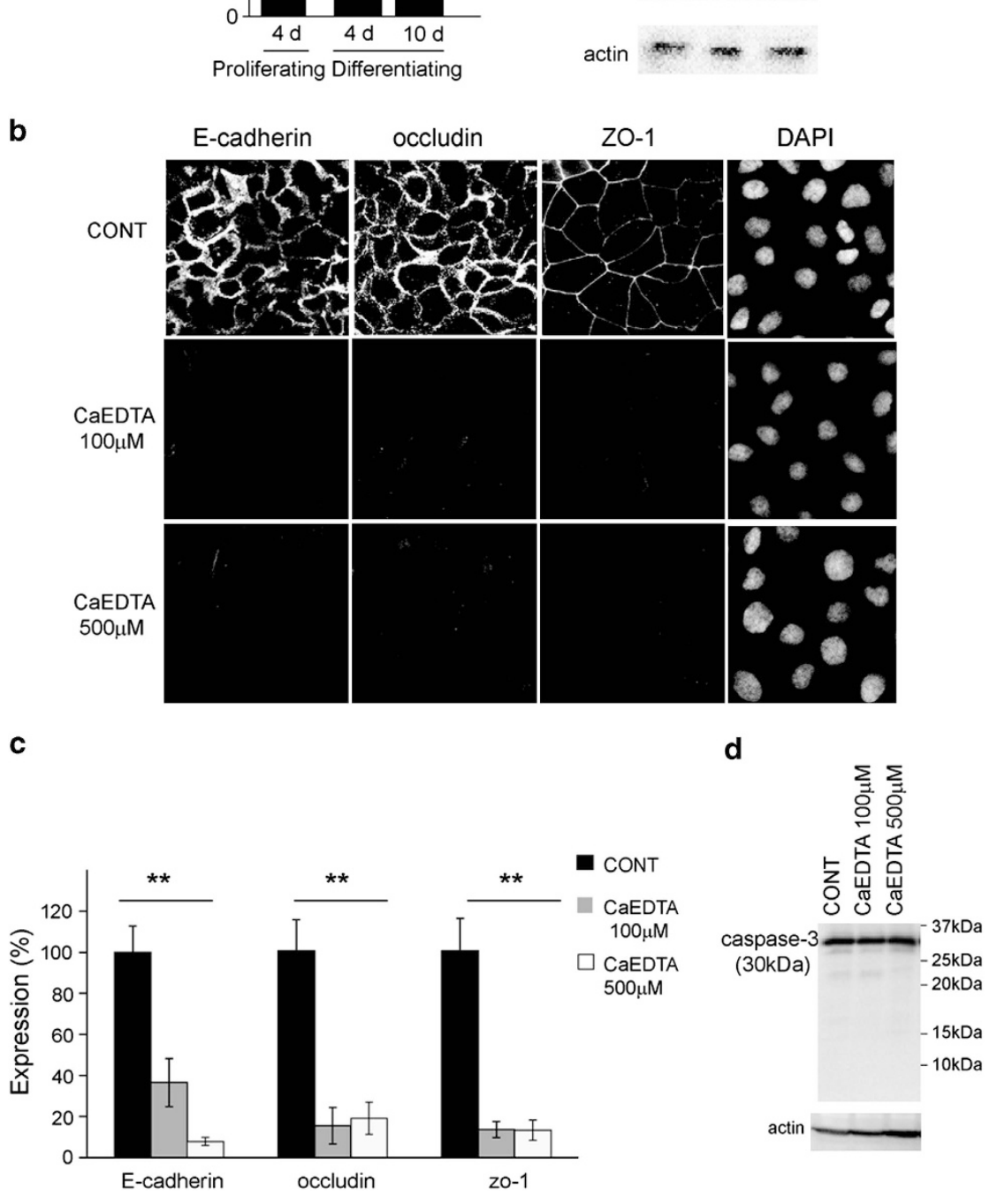

d

Figure 6 Zn2 + regulates barrier formation in Caco-2 colonocytes. (a) Left panel: comparison of ZnR/GPR39 mRNA levels in Caco-2 colonocytes during proliferation and differentiation, using real time PCR. Right panel: representative immunoblots of ZnR/GPR39 expression and actin, used for loading control. (b) Caco-2 colonocytes were allowed to differentiate for 10 days in growth medium with CaEDTA (100 and $500 \mu \mathrm{M}$ ) or without it. Immunofluorescence images of occludin, ZO-1, E-cadherin and DAPI staining are shown. (c) Quantitative analysis of occludin, ZO-1 and E-cadherin expression levels from images as presented in $\mathbf{b}$, shown as percentage of expression level in control cells. (d) Caspase-3 activation in Caco-2 colonocytes treated as in b. Representative immunoblots of caspase-3 and actin, used for loading control. ( $n \geq 3$; ${ }^{*} P<0.05$; $\left.{ }^{* *} P<0.01\right)$

$\mathrm{Zn}^{2+}$-dependent cellular signaling pathways leading to both proliferation and differentiation of colonocytes and that silencing of ZnR/GPR39 diminishes most of the $\mathrm{Zn}^{2+}$. dependent effect. Importantly, we show that knockdown of ZnR/GPR39 expression does not increase cell death but reduces cell numbers, suggesting that ZnR/GPR39 enhances cell proliferation. Interestingly, $\mathrm{Ca}^{2+}$ signaling, such as mediated by ZnR/GPR39, has a role in gastric epithelial repair. $^{35}$ Thus, our results identify the ZnR/GPR39 as the major mediator of $\mathrm{Zn}^{2+}$ signaling leading to growth of colonocytes. Although it is suggested that extracellular $\mathrm{Zn}^{2+}$ levels are extremely low, in the digestive tract $\mathrm{Zn}^{2+}$ released from the liver or found in digested food ${ }^{36,37}$ may be a source for $\mathrm{Zn}^{2+}$ signaling. In addition, $\mathrm{Zn}^{2+}$ can be secreted from epithelial cells, ${ }^{38-40}$ such secretion may paracrinically activate ZnR/GPR39 in neighboring cells. ${ }^{41}$ Also, we previously showed that $\mathrm{Zn}^{2+}$ is released during epithelial cell injury, ${ }^{16}$ and hence, cell death which occurs regularly in this regenerative tissue may also be a source for $\mathrm{Zn}^{2+}$ required to activate ZnR/GPR39 colonocytes. Moreover, accumulation of 
a

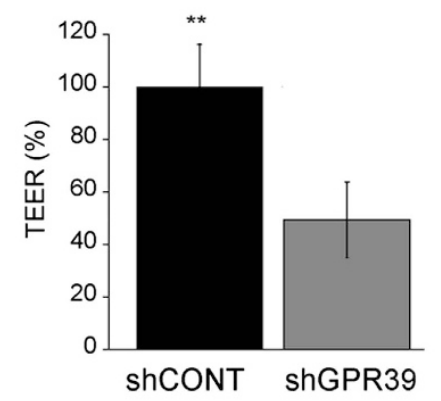

b

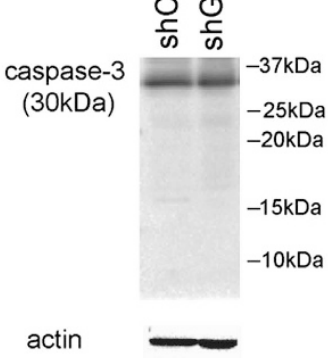

c
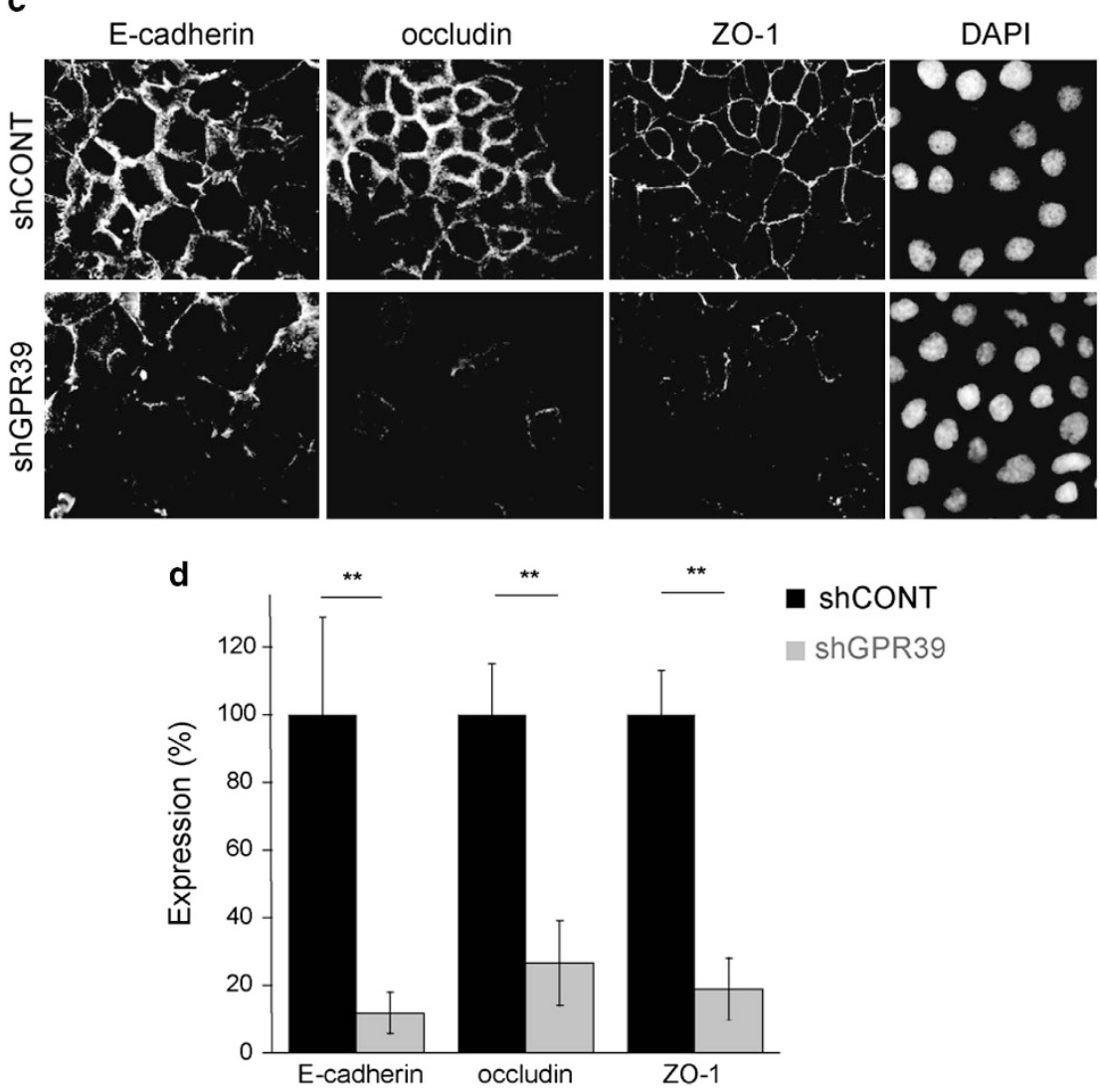

Figure 7 ZnR/GPR39 is essential for the formation of the intestinal barrier. (a) Caco-2 colonocytes grown on permeable supports were allowed to differentiate for 10 days, and transepithelial electrical resistance (TEER) was measured in control cells (shCONT) or ZnR/GPR39-silenced cells (shGPR39). (b) Caspase-3 activation in shCONT and shGPR39 Caco-2 colonocytes following 10 days of differentiation as in a. Representative immunoblots of caspase-3 and actin, used for loading control. (c) Expression of occludin, ZO-1 and E-cadherin following the same experimental paradigm as in a. The cells were fixed and immunofluorescence was used for the detection of occludin, ZO-1, E-cadherin and DAPI staining. (d) Quantitative analysis of occludin, ZO-1 and E-cadherin expression levels presented in c. Images were adjusted to the same threshold and the histogram was produced. Pixel counts were compared between images of shCONT and shGPR39 cells and are presented as a percentage of the shCONT cells. Note that the expression of occludin, ZO-1 and E-cadherin is seen at the periphery of the shCONT cells indicating proper differentiation and formation of the junctional complexes. Silencing of ZnR/GPR39 largely inhibited the expression of occludin, ZO-1 and E-cadherin, that were delocalized. $n \geq 3 ;{ }^{*} P<0.05$; ${ }^{* *} P<0.01$

$\mathrm{Zn}^{2+}$ in colonocytes is triggered by oxidative stress. ${ }^{42,43}$ Interestingly, differentiated Caco-2 colonocytes accumulate numerous $\mathrm{Zn}^{2+}$-containing vesicles stacked at the apical side of the cells, and this $\mathrm{Zn}^{2+}$ is required for cell survival. ${ }^{40} \mathrm{We}$ show here that chelating extracellular $\mathrm{Zn}^{2+}$ in growth media during Caco-2 colonocytes differentiation dramatically inhibits barrier formation and expression of tight and adhering junctional proteins. This result suggests that even in the
Caco-2 colonocytes model, there is sufficient $\mathrm{Zn}^{2+}$ release from the cells to activate signaling regulating differentiation of the cells.

The mTOR signaling pathway integrates signals from multiple inputs, such as growth factors, stress, nutrients and energy. ${ }^{44} \mathrm{~A}$ crucial effector of mTOR signaling is $p 70 \mathrm{~S} 6 \mathrm{~K},{ }^{45} \mathrm{a}$ pathway that is activated by AKT to enhance cell proliferation. Several previous studies demonstrated a role for $\mathrm{Zn}^{2+}$ in 

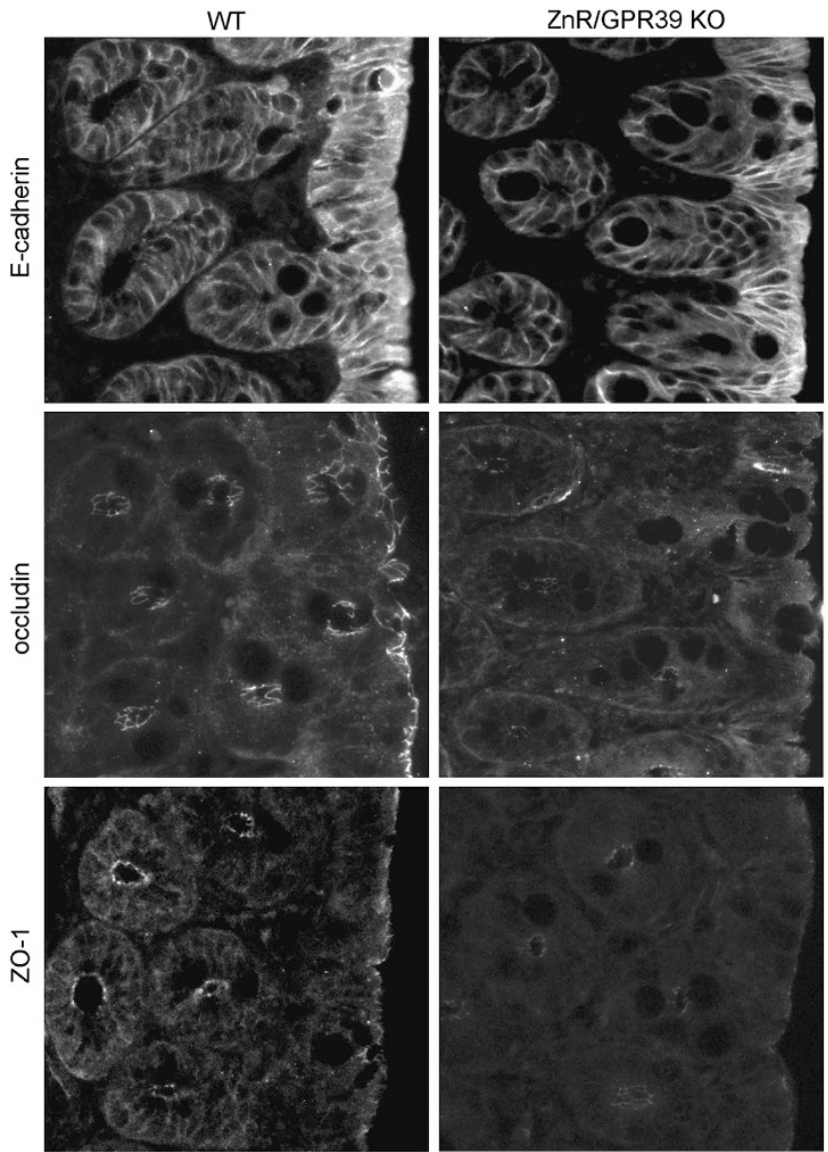

Figure 8 ZnR/GPR39 knockdown impairs the intestinal barrier proteins expression in mouse colon epithelium. Colon tissues of WT and GPR39 KO mice were removed, fixed and immunofluorescently stained for detection of occludin, ZO-1 and E-cadherin. Although the expression of E-cadherin was unaltered in the GPR39 KO mice, the expression of both occludin and ZO-1 was significantly decreased in these mice. Shown is a representative example obtained from at least 24 sections (6 mice per group)

stimulation of the mTOR-signaling pathway in vitro and in vivo. ${ }^{33,46,47}$ For example, the mTOR pathway was activated by $\mathrm{Zn}^{2+}$ in Swiss 3T3 fibroblasts, SHSY5Y neuronal cells and in primary cultured neurons of rat cortical cortex but how $\mathrm{Zn}^{2+}$ interacts with this pathway was not clear. In mouse embryonic stem (ES) cells, $\mathrm{Zn}^{2+}$ stimulated proliferation through the $\mathrm{PISK} / \mathrm{AKT}$, MAPK and the downstream mTOR/p70S6K pathways. ${ }^{46}$ Here, we show that $Z n^{2+}$-induced phosphorylation of mTOR and p70S6K in colonocytes is largely blocked following ZnR/GPR39 silencing or following inhibition of ZnR/GPR39dependent activation of MEK $1 / 2$ or PI3K. Thus, we suggest that $\mathrm{ZnR} / \mathrm{GPR} 39$ signaling is essential for $\mathrm{Zn}^{2+}$-induced mTOR activation. The $\mathrm{Zn}^{2+}$-dependent phosphorylation of p70S6K was further inhibited by rapamycin, indicating that it is phosphorylated by mTORC1, the complex which is linked with cell growth and proliferation. ${ }^{48}$ It is commonly accepted that mTORC1 is activated through the PI3K/AKT pathway, but there are also studies suggesting that growth factors signal to mTORC1 complexes also through the ERK pathway. ${ }^{49}$ Owing to its major role in colonocytes growth, mTOR silencing was suggested as a therapeutic strategy for colorectal cancer. ${ }^{50,51}$ Activation of the mTOR cascade by $\mathrm{Zn}^{2+}$ through
ZnR/GPR39, along with the evidence for a role of ZnR/GPR39 in growth of prostate cancer cells ${ }^{14}$ and keratinocytes ${ }^{16}$ and survival of HT29 colonocytes, ${ }^{15}$ suggest that ZnR/GPR39 is a major regulator of epithelial cells growth.

Previous studies suggested that ZnR/GPR39 may have an oncogenic effect and contribute to the development of malignancies. For example, ZnR/GPR39 silencing in an esophageal squamous cell carcinoma (ESCC) cell line decreased cell proliferation and delayed the cells in the G1/S phase. ${ }^{52}$ In addition, ZnR/GPR39 overexpression was detected in specimens of human ESCC and associated to the malignant development of this carcinoma ${ }^{52}$ but the role of $\mathrm{Zn}^{2+}$ as the ligand of $\mathrm{ZnR} / \mathrm{GPR} 39$ that promotes these tumorigenic processes remained elusive. Our results, however, do not support an oncogenic effect for ZnR/GPR39, as elevated levels of ZnR/GPR39 were found in differentiating Caco-2 cells compared with cells in the proliferative phase. Previous studies showed that $\mathrm{Zn}^{2+}$ induces activation of AP in Caco-2 cells, ${ }^{53}$ human skeletal cells, ${ }^{54}$ and in osteoblastic MC3T3-E1 cells ${ }^{55}$ but what mediates this signaling was unknown. Our results indicate that ZnR/GPR39 mediates $\mathrm{Zn}^{2+}$-dependent AP activity and, therefore, support a role for ZnR/GPR39 in differentiation of colonocytes. It will be interesting to determine whether the differentiation of colonocytes following ZnR/GPR39 activation will result in absorptive enterocytes or Goblet cells lineage. Further support for the role of ZnR/GPR39 in differentiation comes from recent studies, demonstrating that ZnR/GPR39 is expressed during adipocyte differentiation. ${ }^{56}$ In the pancreas, ZnR/GPR39 was strongly upregulated during differentiation of the pluripotent pancreatic cell line AR42J cells towards the endocrine phenotype ${ }^{57}$ Importantly, $\mathrm{Zn}^{2+}$ is secreted from endocrine $\beta$-cells in the pancreas and may trigger ZnR/GPR39 activation and signaling, leading to differentiation of cells. Our results similarly indicate that during differentiation of Caco-2 cells $\mathrm{ZnR} / \mathrm{GPR} 39$ expression is upregulated and may act as a feedback mechanism, triggered by released $\mathrm{Zn}^{2+}$ in the colon, to activate AP and differentiation of colonocytes. Such change in expression level may indicate that the cellular responses mediated by the receptor are tuned by its expression levels, but how the changes in ZnR/GPR39 expression affect cellular signaling requires further study.

In agreement with the important role of ZnR/GPR39 in differentiation of colonocytes, we also show its role in formation of the junctional complexes constituting the epithelial barrier. The expression of occludin and E-cadherin was significantly decreased in ZnR/GPR39-silenced HT29 cells. The colonocytic cell line Caco-2 serves as a better model for colonocytes differentiation as it spontaneously differentiates and develops junctional complexes such as found in the intestinal barrier. Caco-2 cell monolayers grown in $\mathrm{Zn}^{2+}$-deficient media showed a decrease in trans TEER and alterations of tight and adherens junctions with delocalization of ZO-1, occludin, $\beta$-catenin and E-cadherin but the mediator of this effect was not identified. ${ }^{5}$ Moreover, these previous studies did not distinguish between the role of extracellular and intracellular $\mathrm{Zn}^{2+}$ on the formation of the intestinal barrier. We show here that chelation of extracellular $\mathrm{Zn}^{2+}$ is sufficient to inhibit junctional complexes formation. We further show that the differentiation process of 
colonocytes is impaired upon ZnR/GPR39 silencing. In agreement with the $\mathrm{Zn}^{2+}$-deficiency experiment, our results exhibit a decrease in TEER levels to about $50 \%$ of the control cells in the ZnR/GPR39-silenced cells. This was accompanied by a dramatic reduction in occludin, ZO-1 and E-cadherin expression and delocalization of the proteins. Similar effect of ZnR/GPR39 was demonstrated here in vivo by the decrease in tight junction proteins occludin and ZO-1 in the colon epithelium of GPR39 KO mice, indicating that this receptor is essential for the formation of the intestinal barrier in vivo. Importantly, the impaired tight junction organization, manifested by the absence of the tight junction apical proteins, may underlie the GPR39 KO phenotype of enhanced gastric emptying. During physiological cell shedding of the intestinal epithelium redistribution of ZO-1 is a major cellular process which controls the epithelial barrier function. ${ }^{58}$ In contrast to the effects, we observed following ZnR/GPR39 silencing in cultured HT29 and Caco-2 cells and to previous $\mathrm{Zn}^{2+}$ deficiency studies, ${ }^{5}$ the knockdown of ZnR/GPR39 did alter the expression of the adhering junctional protein $\mathrm{E}$-cadherin compared with WT colon tissue. Although the reasons for this discrepancy is not clear, it may result from a compensatory mechanism that develops in the complete knockout model of the mice, as the physical barrier is essential for development of the epithelial layer and colon function. Our results, therefore, suggest that although the structural elements of the epithelial junctions are functional in the colon, the seal of the tight junction proteins is impaired in the absence of $\mathrm{ZnR} /$ GPR39. Thus, we show that ZnR/GPR39 is the missing link between $\mathrm{Zn}^{2+}$ and improved barrier function of differentiated colonocytes.

$\mathrm{Zn}^{2+}$ deficiency impairs the intestinal barrier function, and results in increased permeability and decreased host immunity. For example, studies of the effects of alcohol on the intestinal mucosa suggest that even minor $\mathrm{Zn}^{2+}$ deprivation exaggerates the deleterious effect of alcohol on the epithelial barrier. ${ }^{59}$ On the other hand, $\mathrm{Zn}^{2+}$ can improve barrier function in Crohn's Disease. ${ }^{7}$ Thus far, signaling triggered by $\mathrm{Zn}^{2+}$ that induces these effects was unknown, our results indicate that $\mathrm{ZnR} / \mathrm{GPR} 39$ is a master regulator of $\mathrm{Zn}^{2+}$. dependent signaling in colonocytes. Moreover, by controlling renewal of intestinal epithelium and by the induction of differentiation ZnR/GPR39 enhances barrier function of the colon epithelial layer.

\section{Materials and Methods \\ Cell Cultures. HT29-Cl were grown in standard DMEM medium containing, $100 \mathrm{U} / \mathrm{ml}$ penicillin, $0.1 \mathrm{mg} / \mathrm{ml}$ streptomycin, $2 \mathrm{mM}$ glutamine and $10 \%$ fetal calf serum (Biological Industries, Kibbutz Beit Haemek, Israel), in a $5 \% \mathrm{CO}_{2}$ humidified atmosphere at $37^{\circ} \mathrm{C}$. Caco-2 cells were grown in the same conditions with the addition of $1 \%(\mathrm{v} / \mathrm{v})$ nonessential amino acids (Biological Industries), and $1 \mathrm{mM}$ sodium pyruvate (Sigma-Aldrich, Rehovot, Israel).}

GPR39 gene silencing. HT29 cells were seeded in 60-mm cell-culture dishes (density of $7 \times 10^{5}$ cells/plate) or in 96 -well plates $\left(1.5 \times 10^{4}\right.$ cells/well) $24 \mathrm{~h}$ before transfection and maintained in standard DMEM culture media as described above, without penicillin or streptomycin. Cells were transfected using Lipofectamine 2000 (Invitrogen, Carlsbad, CA, USA) according to the manufacturer's protocol, and used $48 \mathrm{~h}$ post transfection. siRNA constructs (Sigma-Aldrich) were utilized for silencing of target proteins; for ZnR/GPR39: $5^{\prime}-\mathrm{C}$ CAUGGAGUUCUACAGCAU-3', for CLU: 5'-CCAGAGCUCGCCCUUCUAC-3', and siRNA control (scrambled) sequence was 5'-GCCCAGAUCCCUGUACGU-3'.
Stable GPR39 gene silencing. In order to establish stable gene silencing of ZnR/GPR39 in HT29 and Caco-2 cells, transfection was carried out using MISSION Lentiviral Transduction Particles (Sigma-Aldrich) according to manufacturer protocol. Briefly, 20000 cells were seeded a day before infection on 24-well plates. Infection was carried out using five lentivirus clones carrying DNA sequences coding for shRNA compatible with hGPR39, or scrambled sequences, at the multiplicity of infection of 5 . Twelve hours post infection the medium was replaced with growth medium and $48 \mathrm{~h}$ later cells were selected for 14-20 days with $5 \mu \mathrm{g} / \mathrm{ml}$ puromycin, replacing the medium every 3 days. After selection, the cells were grown in growth medium containing $5 \mu \mathrm{g} / \mathrm{ml}$ puromycin, which was removed $48 \mathrm{~h}$ before the experiments.

Protein expression: Cells were seeded on $60-\mathrm{mm}$ plates, and transfected as described above. At $48 \mathrm{~h}$ after transfection (for siRNA transfected cells), or as otherwise stated, cells were harvested into lysis buffer (50 mM HEPES, pH 7.5, $150 \mathrm{mM} \mathrm{NaCl}, 1 \mathrm{mM}$ EDTA, $1 \mathrm{mM}$ EGTA, 10\% glycerol, 1\% Triton X-100, $10 \mu \mathrm{M}$ $\mathrm{MgCl}$, $20 \mathrm{mM} P$-nitrophenyl phosphate, $1 \mathrm{mM} \mathrm{Na} 3 \mathrm{VO} 4,25 \mathrm{mM} \mathrm{NaF}$ ), in the presence of Protease Inhibitor Cocktail (1:25 Complete, Roche, Germany). Lysates were placed on ice for $10 \mathrm{~min}$ and then centrifuged for $30 \mathrm{~min}(14000$ rpm) at $4^{\circ} \mathrm{C}$. Supernatants were collected, protein concentrations were determined using Bio-Rad protein assay, SDS sample buffer was added, and samples were boiled for $5 \mathrm{~min}$ and then frozen at $-80^{\circ} \mathrm{C}$ until used. Whole-cell lysates $(50 \mu \mathrm{g})$ were separated on $10 \%$ or $15 \%$ SDS-PAGE (for GPR39 or caspase-3 detection, respectively) and blotted onto nitrocellulose membranes. For GPR39 detection, the antibodies used were raised against ZnR/GPR39 (The HSHVPEFEVATWIK peptide conjugated to maleimide KLH, Pierce, was used to immunize New Zealand White rabbits according to standard procedures performed at the Antibody Unit in the Department of Biological Services, Weizmann Institute of Science, Israel). For caspase-3 detection, primary antibodies (Cell Signaling, Danvers, MA, USA) were used. Antibodies against $\beta$-actin (MP Biomedicals, Santa Ana, CA, USA) were used for control. Densitometric analysis of GPR39 expression level was performed using EZQuant-Gel image processing and analysis software (EZQuant, Rehovot, Israel). Protein levels were normalized to actin levels, and are presented as percentage of the expression level of WT ZnR/GPR39. Each graph represents an average of at least three independent experiments.

Monitoring Kinase Activation: HT29 cells were seeded on 60-mm culture dishes and serum starved as described above. Cells were treated with $\mathrm{Zn}^{2+}(100 \mu \mathrm{M}$ for $10 \mathrm{~min})$ in Ringer's solution, in the presence or absence of the indicated inhibitors, added $30 \mathrm{~min}$ before $\mathrm{Zn}^{2+}$ treatment (except rapamycin, added $60 \mathrm{~min}$ before $\mathrm{Zn}^{2+}$ treatment). Cells were washed and incubated for an additional 10 min after the $\mathrm{Zn}^{2+}$ treatment to allow kinase phosphorylation. Next, cells were harvested as described above, centrifuged and protein concentrations were determined using Bio-Rad protein assay. Whole-cell lysates $(50 \mu \mathrm{g})$ were separated on $10 \%$ SDS-PAGE, and blotted onto nitrocellulose membranes. The required proteins were detected using specific antibodies raised against the doubly phosphorylated ERK1/2 and total ERK1/2 (Sigma-Aldrich), phosphorylated AKT and total AKT (Santa Cruz Biotechnology, Santa Cruz, CA, USA), p-mTOR (Cell Signaling), phosphorylated p70S6K (Cell Signaling) and actin (MP Biomedicals). Densitometric analysis of expression level was performed using EZQuant-Gel (EZQuant). Phospho-ERK1/2 or AKT levels were normalized against the total ERK1/2 or AKT protein, respectively. Phospho-mTOR and phospho-p70S6K were normalized against actin. Phosphorylation of all the proteins is presented as percentage of the effect triggered by application of $100 \mu \mathrm{M} \mathrm{Zn}{ }^{2+}$. Each graph represents an average of at least three independent experiments.

Calcium imaging: The imaging system consisted of an Axiovert 100 inverted microscope (Zeiss, Oberkochen, Germany), Polychrome V monochromator (TILL Photonics, Graefelfing, Germany), and a SensiCam cooled charge-coupled device (PCO Systems, Kelheim, Germany). Fluorescent imaging measurements were acquired with Imaging Workbench 5 (INDEC Biosystems, Santa Clara, CA, USA). Cells were incubated for 30 min with $2.5 \mu \mathrm{M}$ Fura-2 acetoxymethyl ester (AM; TEF-Labs, Austin, TX, USA) in Ringer's solution with $0.1 \%$ BSA. After dye loading, the cells were washed in Ringer's solution, and cover slides were mounted into a chamber that allowed perfusion. Fura-2 was excited at $340 \mathrm{~nm}$ and $380 \mathrm{~nm}$, and imaged with a 510 -nm long-pass filter. ${ }^{12}$ All results shown are the means of at least three independent experiments, with averaged responses of 30 cells in each experiment. 
Cell proliferation assay: Quantitative sulphorhodamine B (SRB) colorimetric assay was used to determine cell proliferation. ${ }^{60}$ Colorimetric measurement of the dye, bound to basic amino acids, provides an estimate of the total protein mass that is proportional to the cell number. HT29 and Caco-2 cells infected with lentivirus encoding for shRNA's to silence ZnR/GPR39 expression (shGPR39) or a scrambled sequence (shCONT) as described above, were seeded into 96-well plates (20000 cells per well) and grown for the indicated time in growth medium. Cells were fixed using 10\% TCA (trichloroacetic acid) for $1 \mathrm{~h}$ at $4^{\circ} \mathrm{C}$. The supernatant was discarded and plates were washed. Hundred-microliter sulforhodamine B (SRB $0.4 \mathrm{w} / \mathrm{v}$ in $1 \%$ acetic acid) was added and incubated for $10 \mathrm{~min}$ at room temperature. The unbound SRB was removed by washing with $1 \%$ acetic acid. The dye bound to basic amino acids of the cell membrane was solubilized with Tris buffer (10 mM, pH 10.5) and then absorption measurements at $540 \mathrm{~nm}$ by ELISA reader (Molecular Devices, Sunnyvale, CA, USA) were performed to determine relative cell numbers using a calibration curve. Each graph represents an average of at least three independent experiments.

Real Time PCR: Real time PCR was used to estimate the mRNA levels of $\mathrm{ZnR} / \mathrm{GPR} 39$. Cells were seeded on $60-\mathrm{mm}$ plates, and grown for the indicated time. Cells were detached using $0.05 \%$ trypsin (Biological Industries), collected into lysis buffer, and homogenized using QIAshredder kit (QIAGEN, Valencia, CA

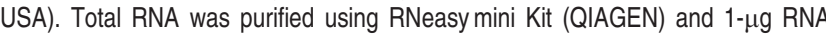
was converted to cDNA using Verso cDNA synthesis Kit (Thermo Scientific, Waltham, MA, USA). CDNA was diluted 1:16, and subjected to real time PCR (Taqman), using ABsolute Blue QPCR kit (Thermo Scientific). The relative quantity of gene expression was analyzed by the $2-\Delta \Delta$ threshold cycle method. ${ }^{61}$ The level of ZnR/GPR39 mRNA was normalized to the endogenous control, $\beta$-actin. Primers and probes were from Solaris (Dharmacon RNAi Technologies, Thermo Scientific). Primers for ZnR/GPR39 mRNA detection: 5'-CATCTTCCTGAGGCTGA-3' and 5'-ATGATCCTCCGTCTGGTTG-3'. Probe sequence: $5^{\prime}$-TATGCTGGATGCCCAAC-3'. Primers for actin: $5^{\prime}$-TGGAGAAAATCTGGCACCAC-3' and $5^{\prime}$-GGTCTCAAA CATGATCTGG-3'. Probe sequence: 5'-ACCGCCAGAAGATGACC-3'.

\section{Immunofluorescence (IF)}

HT29 and Caco-2 cells Preparation. Cells were seeded on glass cover slides (Thermo-scientific) and grown for the indicated period. Antigene retrieval was performed for $2 \mathrm{~min}$ on ice, with pre-extraction buffer $(0.02 \%$ Triton- $X, 100 \mathrm{mM}$ $\mathrm{KCl}, 3 \mathrm{mM} \mathrm{MgCl}, 1 \mathrm{mM} \mathrm{CaCl}, 200 \mathrm{mM}$ sucrose, $10 \mathrm{mM}$ Hepes). Cells were fixed for $30 \mathrm{~min}$ with $4 \%$ Paraformaldehyde (PFA, Sigma Aldrich), permeabilized for 5 min on ice using permeability buffer $(0.05 \%$ Triton- $X)$, and blocked for 30 min using normal goat serum. After rinsing with phosphate-buffered saline (PBS), cells were incubated with antibodies raised against the ZO-1, occludin (Invitrogen, Life Technologies), or E-cadherin (Cell Signaling Technology) for $1 \mathrm{~h}$ at room temperature, extensively rinsed with PBS, and incubated for $1 \mathrm{~h}$ with affinity purified Cy3-conjugated goat anti-rabbit (for detection of ZO-1 and occludin; Jackson ImmunoResearch Laboratories, West Grove, PA, USA) or anti-mouse IgG (for detection of E-cadherin; Jackson ImmunoResearch Laboratories). Samples were mounted with Immuno-mount (Thermo Scientific), or Ultracruz mounting agent containing 4',6-diamidino-2-phenylindole - DAPI (Santa Cruz Biotechnology) for DNA staining, and imaged via a Zeiss Axiomat microscope equipped with appropriate fluorescence barrier and excitation filters. Expression level analysis of the ZO-1, occludin and E-cadhein proteins was done using Adobe Photoshop software. The images, acquired using the same lighting and imaging parameters, were adjusted to the same threshold and a histogram was produced for each picture. The pixel counts, representing the level of expression, for ZnR/GPR39expressing cells in each image (shCONT) were compared with those obtained for ZnR/GPR39-silenced cells (shGPR39). Each graph represents an average of at least four independent experiments, and at least six different fields imaged.

Colon tissues preparation. WT or GPR39 $\mathrm{KO}^{17}$ littermates were used after genotyping using PCR of DNA isolated from mouse tail biopsy samples. Primers $5^{\prime}$ - ACCCTCATCTTGGTGTACCT- $3^{\prime}$ and $5^{\prime}$-TGTAGCGCTCAAAGCTGAG- $3^{\prime}$ amplified a 311 -bp band from the WT allele, whereas primers $5^{\prime}$-GGAACTCT CACTCGACCTGGG-3' and $5^{\prime}$-GCAGCGCATCGCCTTCTATC- $3^{\prime}$ amplified a 262-bp band from the knockout allele. Colon tissues were prepared in accordance with protocols approved by the committee for the Ethical Care and Use of Animals in Research at Ben-Gurion University. Mice at ages of 2-3 weeks were sacrificed and distal colons were removed. Tissues were washed in PBS solution, fixed in
4\% PFA (Sigma Aldrich) for $24 \mathrm{~h}$, and paraffin embedded. Paraffin-embedded tissues sections were cut into $4-\mu \mathrm{m}$ sections, deparaffinized and rehydrated, followed by antigen retrieval using either $0.1 \mathrm{M}$ citric acid monohydrate $(\mathrm{pH} 6$, $10 \mathrm{~min}, 95^{\circ} \mathrm{C}$, for E-cadherin staining) or proteinase digestion $\left(1 \mathrm{mg} / \mathrm{ml}, 37^{\circ} \mathrm{C}\right.$, $10 \mathrm{~min}$ for occluding and ZO-1 staining). Blocking and staining with the different antibodies was performed as described above. At least three different sections were analyzed from six WT mice and six GPR39 KO.

AP activity: HT29 cells infected with lentivirus encoding shGPR39 or shCONT, as described above, were seeded to $80 \%$ confluence in $60-\mathrm{mm}$ plates and $24 \mathrm{~h}$ later butyrate $(5 \mathrm{mM}, 48 \mathrm{~h})$ was added to the growth media. Cells were then harvested and AP activity was measured using SensoLyte Luminescent Alkaline Phosphatase Assay Kit (ANASPEC, Fremont, CA, USA), according to manufacturer protocol. The protein concentrations in the lysate samples were determined using Bio-Rad protein assay, and AP activity was normalized to protein concentration, and compared between shGPR39 and shCONT cells.

TEER measurements: Barrier formation was determined by measuring TEER. ${ }^{62}$ Caco-2 cells were seeded at a density of 150000 per well on a permeable support (12-well Thincert, 0.4- $\mu \mathrm{m}$ pore diameter; Greiner Bio-One $\mathrm{GmbH}$, Frickenhausen, Germany). TEER was monitored on the indicated days using Evom Electrical Resistance System (World Precision Instruments). TEER values are expressed as Ohm (resistance) $\times \mathrm{cm}^{2}$ (surface area of the monolayer) after subtracting the insert resistance value, and are compared between shGPR39 and shCONT Caco-2 cells in the same experiment. The graph represents an average of three different experiments.

Statistical Analysis. Data are expressed as means \pm S.E.M. Each treatment group was evaluated using the Student's $t$-test or ANOVA followed by Tukey-Kramer test, as appropriate. ${ }^{*} P<0.05$; ${ }^{* \star} P<0.01$;

\section{Conflict of Interest}

The authors declare no conflict of interest.

Acknowledgements. This work was supported by the Israel Science Foundation (Grant 513/09 to M.H.). The GPR39 KO mice were kindly provided by $D$ Moechars from Johnson \& Johnson Pharmaceutical Research and Development, a Division of Janssen Pharmaceutica.

1. Nusrat A, Turner JR, Madara JL. Molecular physiology and pathophysiology of tight junctions. IV. Regulation of tight junctions by extracellular stimuli: nutrients, cytokines, and immune cells. Am J Physiol Gastrointest Liver Physiol 2000; 279: G851-G857.

2. Vereecke L, Beyaert R, van Loo G. Enterocyte death and intestinal barrier maintenance in homeostasis and disease. Trends Mol Med 2011; 17: 584-593.

3. Traber PG. Differentiation of intestinal epithelial cells: lessons from the study of intestinespecific gene expression. J Lab Clin Med 1994; 123: 467-477.

4. Hoque KM, Binder HJ. Zinc in the treatment of acute diarrhea: current status and assessment. Gastroenterology 2006; 130: 2201-2205.

5. Finamore A, Massimi M, Conti Devirgiliis L, Mengheri E. Zinc deficiency induces membrane barrier damage and increases neutrophil transmigration in Caco-2 cells. J Nutr 2008: 138: 1664-1670.

6. Ziegler TR, Evans ME, Fernandez-Estivariz C, Jones DP. Trophic and cytoprotective nutrition for intestinal adaptation, mucosal repair, and barrier function. Annu Rev Nutr 2003; 23: 229-261.

7. Hering NA, Schulzke JD. Therapeutic options to modulate barrier defects in inflammatory bowel disease. Dig Dis 2009; 27: 450-454.

8. Sturniolo GC, Fries W, Mazzon E, Di Leo V, Barollo M, D'Inca R. Effect of zinc supplementation on intestinal permeability in experimental colitis. J Lab Clin Med 2002; 139: 311-315.

9. Lukacik M, Thomas RL, Aranda JV. A meta-analysis of the effects of oral zinc in the treatment of acute and persistent diarrhea. Pediatrics 2008; 121: 326-336.

10. Chen BW, Wang HH, Liu JX, Liu XG. Zinc sulphate solution enema decreases inflammation in experimental colitis in rats. J Gastroenterol Hepatol 1999; 14: 1088-1092.

11. Tran CD, Ball JM, Sundar S, Coyle P, Howarth GS. The role of zinc and metallothionein in the dextran sulfate sodium-induced colitis mouse model. Dig Dis Sci 2007; 52: 2113-2121.

12. Hershfinkel M, Moran A, Grossman N, Sekler I. A zinc-sensing receptor triggers the release of intracellular $\mathrm{Ca} 2+$ and regulates ion transport. Proc Natl Acad Sci USA 2001; 98: $11749-11754$ 
13. Azriel-Tamir H, Sharir H, Schwartz B, Hershfinkel M. Extracellular zinc triggers ERKdependent activation of $\mathrm{Na}+/ \mathrm{H}+$ exchange in colonocytes mediated by the zinc-sensing receptor. J Biol Chem 2004; 279: 51804-51816.

14. Dubi N, Gheber L, Fishman D, Sekler I, Hershfinkel M. Extracellular zinc and zinc-citrate, acting through a putative zinc-sensing receptor, regulate growth and survival of prostate cancer cells. Carcinogenesis 2008; 29: 1692-1700.

15. Cohen L, Azriel-Tamir H, Arotsker N, Sekler I, Hershfinkel M. Zinc sensing receptor signaling, mediated by GPR39, reduces butyrate-induced cell death in HT29 colonocytes via upregulation of clusterin. PLoS One 2012; 7: e35482.

16. Sharir $H$, Zinger A, Nevo A, Sekler I, Hershfinkel M. Zinc released from injured cells is acting via the $\mathrm{Zn} 2+$-sensing receptor, $\mathrm{ZnR}$, to trigger signaling leading to epithelial repair. J Biol Chem 2010; 285: 26097-26106.

17. Moechars D, Depoortere I, Moreaux B, de Smet B, Goris I, Hoskens L et al. Altered gastrointestinal and metabolic function in the GPR39-obestatin receptor-knockout mouse. Gastroenterology 2006; 131: 1131-1141.

18. Aliaga JC, Deschenes C, Beaulieu JF, Calvo EL, Rivard N. Requirement of the MAP kinase cascade for cell cycle progression and differentiation of human intestinal cells. Am J Physiol 1999; 277(3 Pt 1): G631-G641.

19. Bouchard V, Demers MJ, Thibodeau S, Laquerre V, Fujita N, Tsuruo T et al. Fak/Src signaling in human intestinal epithelial cell survival and anoikis: differentiation state-specific uncoupling with the PI3-K/Akt-1 and MEK/Erk pathways. J Cell Physiol 2007; 212: 717-728.

20. Buccigrossi V, Giannattasio A, Armellino C, Lo Vecchio A, Caiazzo MA, Guarino A. The functional effects of nutrients on enterocyte proliferation and intestinal ion transport in early infancy. Early Hum Dev 2010; 86(Suppl 1): 55-57.

21. Hinnebusch BF, Siddique A, Henderson JW, Malo MS, Zhang W, Athaide CP et al. Enterocyte differentiation marker intestinal alkaline phosphatase is a target gene of the gut-enriched Kruppel-like factor. Am J Physiol Gastrointest Liver Physiol 2004; 286: G23-G30.

22. Wang $Q$, Zhou $Y$, Jackson LN, Johnson SM, Chow CW, Evers BM. Nuclear factor of activated T cells (NFAT) signaling regulates PTEN expression and intestinal cell differentiation. Mol Biol Cell 2011; 22: 412-420.

23. Domokos M, Jakus J, Szeker K, Csizinszky R, Csiko G, Neogrady Z et al. Butyrate-induced cell death and differentiation are associated with distinct patterns of ROS in HT29-derived human colon cancer cells. Dig Dis Sci 2010; 55: 920-930.

24. Graz CJ, Cowley HM. Energy state in HT-29 cells is linked to differentiation. In Vitro Cell Dev Biol Anim 1997; 33: 277-281.

25. Schwartz B, Lamprecht SA, Polak-Charcon S, Niv Y, Kim YS. Induction of the differentiated phenotype in human colon cancer cell is associated with the attenuation of subcellular tyrosine phosphorylation. Oncol Res 1995; 7: 277-287.

26. Augeron C, Laboisse CL. Emergence of permanently differentiated cell clones in a human colonic cancer cell line in culture after treatment with sodium butyrate. Cancer Research 1984; 44: 3961-3969.

27. Gout S, Marie C, Laine M, Tavernier G, Block MR, Jacquier-Sarlin M. Early enterocytic differentiation of HT-29 cells: biochemical changes and strength increases of adherens junctions. Exp Cell Res 2004; 299: 498-510.

28. Shore EM, Nelson WJ. Biosynthesis of the cell adhesion molecule uvomorulin (E-cadherin) in Madin-Darby canine kidney epithelial cells. J Biol Chem 1991; 266: 19672-19680.

29. Bolte G, Beuermann K, Stern M. The cell lines Caco-2, T84, and Ht-29: models of enterocytic differentiation and function. J Pediatr Gastroenterol Nutr 1997; 24: 473.

30. Duff M, Ettarh RR. Crypt cell production rate in the small intestine of the zinc-supplemented mouse. Cells Tissues Organs 2002; 172: 21-28.

31. Park KS, Lee NG, Lee KH, Seo JT, Choi KY. The ERK pathway involves positive and negative regulations of $\mathrm{HT}-29$ colorectal cancer cell growth by extracellular zinc. Am J Physiol Gastrointest Liver Physiol 2003; 285: G1181-G1188.

32. Samet JM, Graves LM, Quay J, Dailey LA, Devlin RB, Ghio AJ et al. Activation of MAPKs in human bronchial epithelial cells exposed to metals. Am J Physiol 1998; 275(3 Pt 1): L551-L558.

33. Kim S, Jung Y, Kim D, Koh H, Chung J. Extracellular zinc activates p70 S6 kinase through the phosphatidylinositol 3-kinase signaling pathway. J Biol Chem 2000; 275: 25979-25984.

34. Huang JS, Mukherjee JJ, Chung T, Crilly KS, Kiss Z. Extracellular calcium stimulates DNA synthesis in synergism with zinc, insulin and insulin-like growth factor I in fibroblasts. Eur J Biochem 1999; 266(Germany):pp 943-951.

35. Aihara E, Hentz CL, Korman AM, Perry NP, Prasad V, Shull GE et al. In vivo epithelial wound repair requires mobilization of endogenous intracellular and extracellular calcium. J Biol Chem 2013; 288: 33585-33597.

36. Krebs NF. Overview of zinc absorption and excretion in the human gastrointestinal tract. J Biol Nutr 2000; 130: 1374S-1377S.

37. Hara $\mathrm{H}$, Konishi A, Kasai T. Contribution of the cecum and colon to zinc absorption in rats. J Nutr 2000; 130: 83-89.

38. Giblin LJ, Chang CJ, Bentley AF, Frederickson C, Lippard SJ, Frederickson CJ. Zincsecreting Paneth cells studied by ZP fluorescence. J Histochem Cytochem 2006; 54: 311-316.

39. Frederickson CJ, Perez-Clausell J, Danscher G. Zinc-containing 7S-NGF complex. Evidence from zinc histochemistry for localization in salivary secretory granules. J Histochem Cytochem 1987; 35: 579-583.
40. Ranaldi G, Ferruzza S, Canali R, Leoni G, Zalewski PD, Sambuy Y et al. Intracellular zinc is required for intestinal cell survival signals triggered by the inflammatory cytokine TNFalpha. J NutrBiochem 2013; 24: 967-976.

41. Sharir $\mathrm{H}$, Hershfinkel $\mathrm{M}$. The extracellular zinc-sensing receptor mediates intercellular communication by inducing ATP release. Biochem Biophys Res Commun 2005; 332 : 845-852.

42. Cima RR, Dubach JM, Wieland AM, Walsh BM, Soybel DI. Intracellular $\mathrm{Ca}(2+)$ and $\mathrm{Zn}(2+)$ signals during monochloramine-induced oxidative stress in isolated rat colon crypts. Am J Physiol Gastrointest Liver Physiol 2006; 290: G250-G261.

43. Walsh BM, Naik HB, Dubach JM, Beshire M, Wieland AM, Soybel DI. Thiol-oxidant monochloramine mobilizes intracellular $\mathrm{Ca} 2+$ in parietal cells of rabbit gastric glands. $\mathrm{Am}$ J Physiol Cell Physiol 2007; 293: C1687-C1697.

44. Efeyan A, Sabatini DM. mTOR and cancer: many loops in one pathway. Curr Opin Cell Biol 2010; 22: 169-176.

45. Dann SG, Selvaraj A, Thomas G. mTOR Complex1-S6K1 signaling: at the crossroads of obesity, diabetes and cancer. Trends Mol Med 2007; 13: 252-259.

46. Ryu JM, Lee MY, Yun SP, Han HJ. Zinc chloride stimulates DNA synthesis of mouse embryonic stem cells: involvement of PI3K/Akt, MAPKs, and mTOR. J Cell Physiol 2009; 218: $558-567$.

47. McClung JP, Tarr TN, Barnes BR, Scrimgeour AG, Young AJ. Effect of supplemental dietary zinc on the mammalian target of rapamycin (mTOR) signaling pathway in skeletal muscle and liver from post-absorptive mice. Biol Trace Elem Res 2007; 118: 65-76.

48. Bhaskar PT, Hay N. The two TORCs and Akt. Dev Cell 2007; 12: 487-502.

49. Shaw RJ, Cantley LC. Ras PI(3)K and mTOR signalling controls tumour cell growth. Nature 2006; 441: 424-430.

50. Zhang YJ, Dai $Q$, Sun DF, Xiong H, Tian XQ, Gao FH et al. mTOR signaling pathway is a target for the treatment of colorectal cancer. Ann Surg Oncol 2009; 16: 2617-2628.

51. Francipane MG, Lagasse E. mTOR pathway in colorectal cancer: an update. Oncotarget 2013; 5: 49-66.

52. Xie F, Liu H, Zhu YH, Qin YR, Dai Y, Zeng T et al. Overexpression of GPR39 contributes to malignant development of human esophageal squamous cell carcinoma. BMC Cancer 2011; 11: 86 .

53. Zodl B, Zeiner M, Sargazi M, Roberts NB, Marktl W, Steffan I et al. Toxic and biochemical effects of zinc in Caco-2 cells. J Inorg Biochem 2003; 97: 324-330.

54. Hall SL, Dimai HP, Farley JR. Effects of zinc on human skeletal alkaline phosphatase activity in vitro. Calcif Tissue Int 1999; 64: 163-172.

55. Seo HJ, Cho YE, Kim T, Shin HI, Kwun IS. Zinc may increase bone formation through stimulating cell proliferation, alkaline phosphatase activity and collagen synthesis in osteoblastic MC3T3-E1 cells. Nutr Res Pract 2010; 4: 356-361.

56. Gurriaran-Rodriguez U, Al-Massadi O, Roca-Rivada A, Crujeiras AB, Gallego R, Pardo M et al. Obestatin as a regulator of adipocyte metabolism and adipogenesis. J Cell Mol Med 2011; 15: 1927-1940.

57. Holst B, Egerod KL, Jin C, Petersen PS, Ostergaard MV, Hald J et al. G protein-coupled receptor 39 deficiency is associated with pancreatic islet dysfunction. Endocrinology 2009; 150: 2577-2585.

58. Guan Y, Watson AJ, Marchiando AM, Bradford E, Shen L, Turner JR et al. Redistribution of the tight junction protein ZO-1 during physiological shedding of mouse intestinal epithelial cells. Am J Physiol Cell Physiol 2011; 300: C1404-C1414.

59. Zhong W, Zhao Y, Sun X, Song Z, McClain CJ, Zhou Z. Dietary zinc deficiency exaggerates ethanol-induced liver injury in mice: involvement of intrahepatic and extrahepatic factors. PLoS One 2013; 8: e76522.

60. Keepers YP, Pizao PE, Peters GJ, van Ark-Otte J, Winograd B, Pinedo HM. Comparison of the sulforhodamine $B$ protein and tetrazolium (MTT) assays for in vitro chemosensitivity testing. Eur J Cancer 1991; 27: 897-900.

61. Ganaiem M, AbuElhija M, Lunenfeld E, Cherniy N, Weisze N, Itach SB et al. Effect of interleukin-1 receptor antagonist gene deletion on male mouse fertility. Endocrinology 2009; 150: 295-303.

62. Ferruzza S, Scacchi M, Scarino ML, Sambuy Y. Iron and copper alter tight junction permeability in human intestinal Caco-2 cells by distinct mechanisms. Toxicol In Vitro 2002; 16: 399-404.

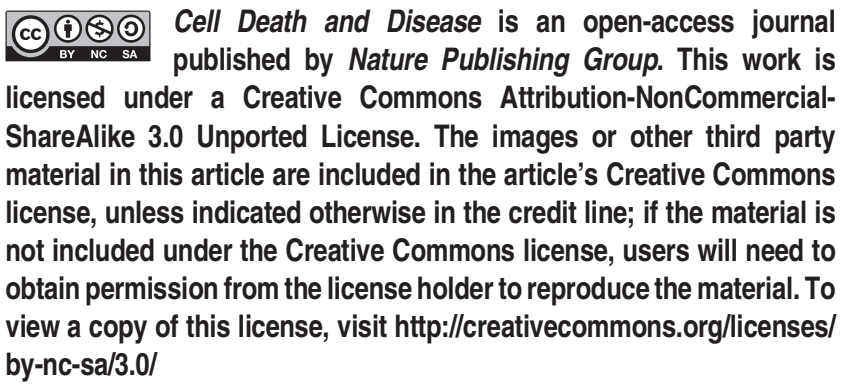

